\title{
The ginkgophytes from the German Kupferschiefer (Permian), with considerations on the taxonomic history and use of Baiera and Sphenobaiera
}

\author{
KATHLEEN BAUER, EVELyn KUStATSCHER \& MichaEL KRINGS
}

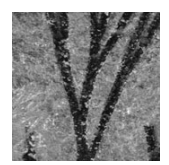

\begin{abstract}
Ginkgophyte foliage fossils (impressions and compressions lacking cuticle) from several of the historical Kupferschiefer localities in Germany have been re-studied using macromorphometry. Baiera digitata is by far the most common ginkgophyte in the Kupferschiefer, while other taxa are relatively rare. A new taxon, for which the name Baiera mansfeldensis is proposed, differs from $B$. digitata in having a much thinner, curved petiole and a curved lamina, as well as a narrow basal angle. Esterella gracilis, a taxon previously known exclusively from France, is reported for the first time from Germany. The foliage genera Baiera and Sphenobaiera have a complicated taxonomic history, and the problematic contiguity that exists between the two taxa has lead to considerable confusion. It appears that the radiation of the ginkgophytes started well before the end-Permian mass-extinction, and that Permian ginkgophytes were more diverse than previously believed. - Key words: Esterella, Ginkgophyta, late Permian, radiation, foliage fossil, macromorphometry, Central European Basin, Germany.
\end{abstract}

BAUER, K., KUSTATSCHER, E. \& KRINGS, M. 2013. The ginkgophytes from the German Kupferschiefer (Permian), with considerations on the taxonomic history and use of Baiera and Sphenobaiera. Bulletin of Geosciences 88(3), 539-556 (7 figures, 2 tables). Czech Geological Survey, Prague. ISSN 1214-1119. Manuscript received November 9, 2012; accepted in revised form February 18, 2013; published online April 5, 2013; issued July 3, 2013.

Kathleen Bauer (corresponding author) \& Evelyn Kustatscher, Naturmuseum Südtirol, Bindergasse 1, 39100 Bolzano/Bozen, Italy; Kathleen.Bauer@naturmuseum.it, Evelyn.Kustatscher@naturmuseum.it・ Michael Krings, Department für Geo- und Umweltwissenschaften, Paläontologie und Geobiologie, Ludwig-Maximilians-Universität, and Bayerische Staatssammlung für Paläontologie und Geologie, Richard-Wagner-Straße 10, 80333 München, Germany; m.krings@lrz.uni-muenchen.de

The ginkgophytes are a group of gymnosperms that probably originated in the late Palaeozoic. However, persuasive fossils of Palaeozoic ginkgophytes are rare (Taylor $e t$ al. 2009). Apart from the enigmatic Permo-Carboniferous taxa Ginkgophytopsis, Ginkgophyllum, and Dicranophyllum (Gothan \& Kukuk 1933, Barthel 1977, Yao 1989, Zhou 2007), several putative ginkgophytes or ginkgophyte precursors have been described from the Permian (for details, see Zalessky 1912, Meyen 1988, Zhou 2009, Taylor et al. 2009). The only bona fide Permian ginkgophyte from Angara is Kerpia-like leaves associated with Karkenia-type ovulate organs (Naugolnykh 2007). Other Angaran foliage taxa such as Ginkgophyllum Saporta, 1875, Ginkgopsis Zalessky, 1912, Glotophyllum Zalessky, 1912, Meristophyllum Zalessky, 1937, Nepheropsis Zalessky, 1912, Psygmophyllum Schimper, 1870, and Rhipidopsis Schmalhausen, 1879 remain insufficiently understood or are of uncertain systematic attribution (Seward 1919, Meyen 1988, Taylor et al. 2009). Permian putative ginkgophytes from the southern hemisphere include Polysper- mophyllum Archangelsky \& Cúneo, 1990 from Argentina, as well as Ginkgoites-type foliage from India (Bajpai 1991, Maheshwari \& Bajpai 1992) and the Permo-Carboniferous of Argentina (Dijkstra 1973, Cúneo 1987), South Africa (Plumstead 1961), and the Congo (Høeg \& Bose 1960). However, information on the epidermal anatomy that could be used to positively identify the affinities of these fossils is lacking. Finally, Sphenobaiera-type leaves have been described from the lower Permian of Antarctica (Taylor \& Taylor 1993) and possibly also from the Permian of South Africa (Zhou 2009). All late Palaeozoic ginkgophyte foliage fossils from Europe have been assigned to either Baiera digitata or, after Florin introduced the new name Sphenobaiera for nonpetiolate ginkgophyte foliage from Franz-Joseph-Land (Florin 1936a, b), to Sphenobaiera digitata. However, the use of both names has not been consistent in the past and has varied between different authors (see below).

Late Permian ginkgophytes are generally believed to be poorly diversified (1 genus, 3 species; Zhou \& Wu 2006), although a newly described flora from the Bletterbach 
gorge in northern Italy appears to provide evidence to the contrary (Kustatscher et al. 2012). According to this study, at least two additional leaf types co-occur with Baiera digitata or Sphenobaiera digitata in the Bletterbach flora. Moreover, several late Permian wood types with probable affinities to the ginkgophytes have recently been reported from China, including Proginkgoxylon Zheng \& Zhang, 2008 (in Zheng et al. 2008) and Palaeoginkgoxylon zhoui Feng et al., 2010 (Zheng et al. 2008, Feng et al. 2010). Nevertheless, the generally poor and fragmentary preservation of most Palaeozoic ginkgophytes or ginkgophyte-like fossils renders assessment of ginkgophyte diversity during this period of time a challenging task. As a result, little is known about the early diversification of this group of plants. Moreover, no consensus exists with regard to the classification and phylogenetic relationship of the Palaeozoic ginkgophytes (for details see Zhou 2009, Taylor et al. 2009).

Late Permian floras are generally rare, especially in Europe and North-America, and our knowledge about these floras is largely based on the Kupferschiefer of the Central European Basin. Although Kupferschiefer fossils have been studied intensively since the mid- $19^{\text {th }}$ century (e.g., Germar 1840, Althaus 1847, Solms-Laubach 1884, Gothan \& Nagalhard 1921, Schweitzer 1960), the ginkgophyte fossils preserved in this important deposit remain incompletely understood. All ginkgophyte remains from the German Kupferschiefer have historically been assigned to either Baiera digitata (Brongniart) Heer, 1876 (Weigelt 1928, 1932) or Sphenobaiera digitata (Brongniart) Florin, 1936 (e.g., Haubold \& Schaumberg 1985, Schweitzer 1986), primarily because of the presumption that the leaves of these fossil taxa exhibit a similarly high intraspecific variability as the leaves of the extant Ginkgo biloba. However, most of the fossils are fragmentary impressions or compressions lacking cuticle that render a clear discrimination of macromorphologically similar taxa difficult.

In this study, we use morphometrical analyses to re-assess the ginkgophyte leaves from the German Kupferschiefer. This approach has been employed because mathematical and trigonometrical analyses can help to reconstruct the leaf shape even if only fragments are preserved. Our results suggest that a higher ginkgophyte diversity than previously assumed existed in the Central European late Permian (at least two bona fide and one putative taxa). Moreover, we demonstrate that morphometry represents a valuable tool for safely identifying fragmentary foliage fossils that do not yield cuticles.

\section{Historical background}

When the first fossils of ginkgophyte leaves were discovered in the early $19^{\text {th }}$ century, it was widely believed that they represented fossilized algae; this is reflected in names such as Zonarites Sternberg 1833; Fucoides Brongniart, 1828 (today used for ichnofossils; Taylor et al. 2009) and Cyclopteris Brongniart, 1828 (today used for basal pinnules in certain neuropterid pteridosperms; Taylor et al. 2009). Braun (1843) introduced the name Baiera for fossils from the Rhaetio-Liassic of Bayreuth (Germany) that he interpreted as ginkgophytes. In the generic diagnosis this author included descriptions of the leaves and female fructifications: The genus Baiera is characterized by repeatedly dichotomizing primary veins. The sporocarps form capsules with pedunculate ovaries and are arranged ternarily or bi-ternarily. Although mentioned in the original diagnosis of the genus, the female fructification was not included in the specific diagnosis of the only taxon described by Braun (1843), nor was it figured. The fructification mentioned by Braun probably corresponds to Stachyopitys preslii Schenk, 1867, a male reproductive structure later attributed to Schmeissneria Kirchner \& Van Konijnenburg-van Cittert, 1994 (Van Konijenburg-van Cittert, pers. comm. 2012).

A few years earlier, Sternberg $(1825$, p. 28 , pl. 47, fig. 2) described Bajera scanica from the Cretaceous of Sweden. However, Halle (1908) assigned the specimens on which B. scanica was founded to Equisetites scanicus (Sternberg) Halle, 1908, and thus the genus Bajera Sternberg, 1825 was left without types and therefore subsequently rejected (Kilpper 1969). The genus Baiera Braun, 1843 was thereafter emended and used in various ways. For example, Heer (1876) emended Braun's (1843) original diagnosis to include the presence of fine veins between the vascular strands as an important character. According to Renault (1888), Baiera leaves are deeply dissected into linear segments with numerous fine veins that run parallel. Frentzen (1922) used the name for more or less petiolate leaves with narrow-linear dichotomous segments that may possess a dissected margin. On the other hand, Harris (1935) used Baiera for wedge-shaped leaves lacking a distinct petiole, but without emending the diagnosis of Braun (1843). Harris (1935) proposed usage of the genus Ginkgoites Seward, 1919 for all leaves characterized by a distinct petiole (Harris 1935). In 1936, Florin emended the original diagnosis (i.e. Braun 1843), and used Baiera for leaves with a distinct petiole and a semicircular to broadly triangular shape. The lamina is deeply dissected into several primary segments, which may be arranged into two groups. The primary segments are deeply bifurcated at least once, but normally more than once. All segments are more or less linear and do not contain more than 2-4 parallel veins. The type species of Baiera Braun, 1843 is Baiera muensteriana (Presley) Heer, 1876 from the Jurassic of Bavaria (Germany). Since the illustration of the original specimen figured by Braun (1843, B. dichotoma, pl. 7, figs $1-5$ ) shows a broadly triangular and petiolate leaf with 


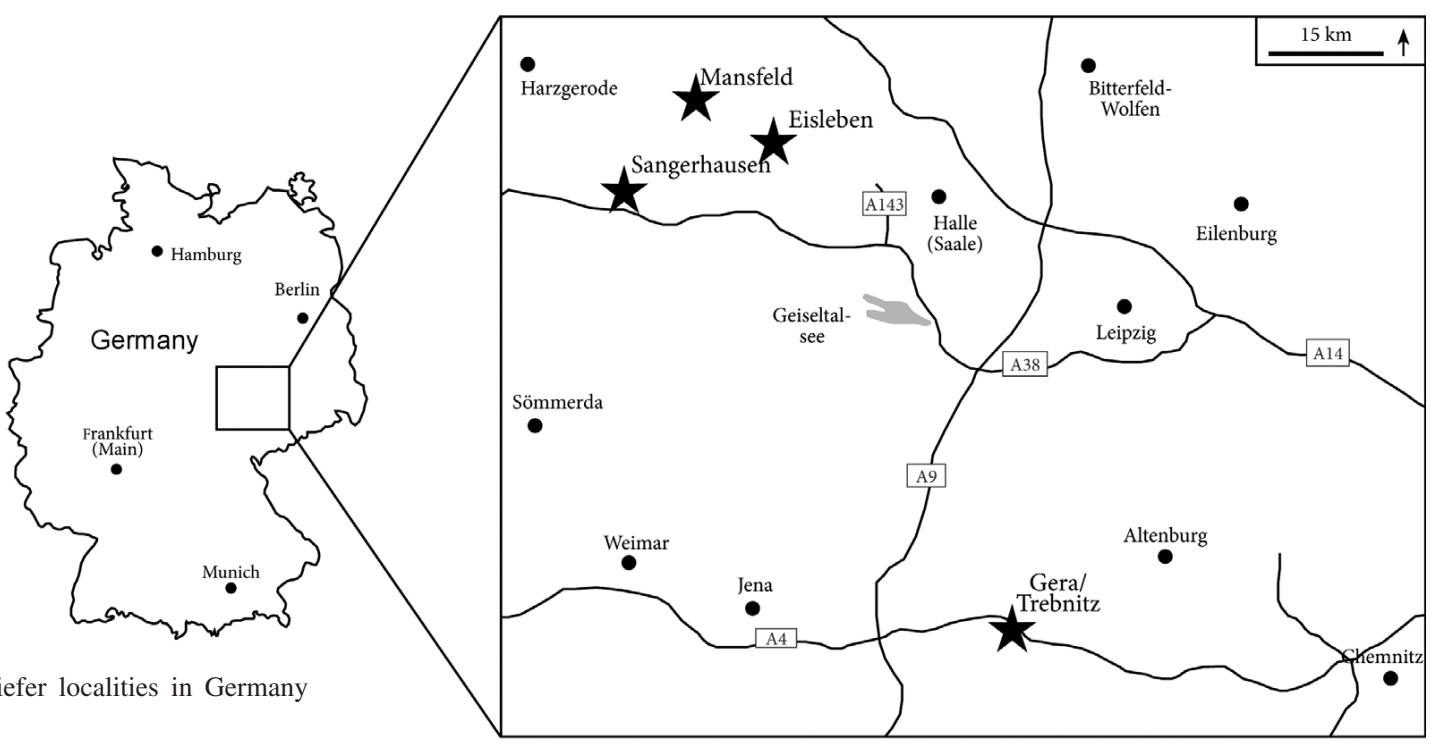

Figure 1. Kupferschiefer localities in Germany (black asterisks).

segments arranged into two groups and deep bifurcation, we suggest to follow the emended diagnosis as proposed by Florin (1936).

Moreover, Florin (1936a, b) introduced the genus Sphenobaiera for certain Mesozoic ginkgophytes from Franz-Joseph-Land (Russia) originally described as Baiera. According to Florin's diagnosis of Sphenobaiera, leaves assignable to this taxon lack a distinct petiole, but rather are wedge-shaped down to the base. The lamina is more or less broadly triangular and deeply dissected into 2-5 primary segments, which may be arranged into two groups and are again at least once bifurcate. As type species, Florin (1936a) designated Sphenobaiera spectabilis (Nathorst) Florin, 1936. Unfortunately, the genus Sphenobaiera was subsequently used widely without paying attention to the presence or absence of a distinct petiole, despite the fact that the absence of a petiole is an important diagnostic character. For example, Stoneley (1958) described late Permian ginkgophyte remains from England as Sphenobaiera digitata (Brongniart) Florin, 1936 although the leaves have a distinct petiole. Also the petiolate ginkgophyte remains from the Kupferschiefer of Germany initially described as Baiera digitata Brongniart, 1828 were later variously referred to Sphenobaiera digitata (e.g., Haubold \& Schaumberg 1985). Harris \& Millington (1974) emended the diagnosis of Florin (1936a) to include more or less broadly wedge-shaped leaves that are "shed separately". A petiole does not exist and the lamina is forking at least once, while the veins are forking repeatedly and run parallel to the distal margin.

In conclusion, Sphenobaiera should be used exclusively for deeply dissected and wedge-shaped leaves with dichotomous venation that lack a distinct petiole, while Baiera should be used only if a distinct petiole (part below the lamina that is more axis-like and consistent in width) is present.

\section{Material and methods}

\section{Stratigraphical setting and age}

The depositional area of the Kupferschiefer developed after the Variscan orogeny by the formation of the Central European Basin, also known as the Southern Permian Basin (Doornenbal \& Stevenson 2010), extending from England to Poland. During the Zechstein (Wuchiapingian, late Permian) nearly the entire area from the North Sea to southern Germany was covered by this epicontinental ba$\sin$. The central part of the basin was situated north of Hamburg (Germany) with a sedimentary succession of about $3.5 \mathrm{~km}$ for the whole 7-8 Zechstein cycles (Bachmann 2008a). Repeated transgressions and regressions, as well as tectonically-caused closures of the connection to the open sea during the Zechstein, caused the cyclic building of evaporites (Bachmann 2008b, Radzinski 2008). The Kupferschiefer has an age of 258-257 Ma (Bachmann 2008a). It represents the lowermost part of the first cycle, the Werra Formation (lower Lopingian, Wuchiapingian). Near Merseburg (Saxony-Anhalt) the Kupferschiefer reaches its greatest thickness of approximately $4 \mathrm{~m}$, while in other parts of the Southern Permian Basin it reaches only between 0.5 (Calvörde, Saxony-Anhalt; Radzinski 2008) and $1 \mathrm{~m}$ (Thuringia; Langbein \& Seidel 2003) in thickness. The finely laminated black marl clays are indicative of a lack of freshwater supply and the development of anoxic conditions during sedimentation. The water depth must have been between 200 and $300 \mathrm{~m}$ (Radzinski 2008).

The fossil sites Mansfeld and Sangerhausen (see Fig. 1) are located on the southern margin of the Southern Permian Basin. In these two areas the Kupferschiefer is approximately $0.3-0.6 \mathrm{~m}$ thick and yields copper- and other nonferrous heavy metal sulphides (Radzinski 2008). Due to the 


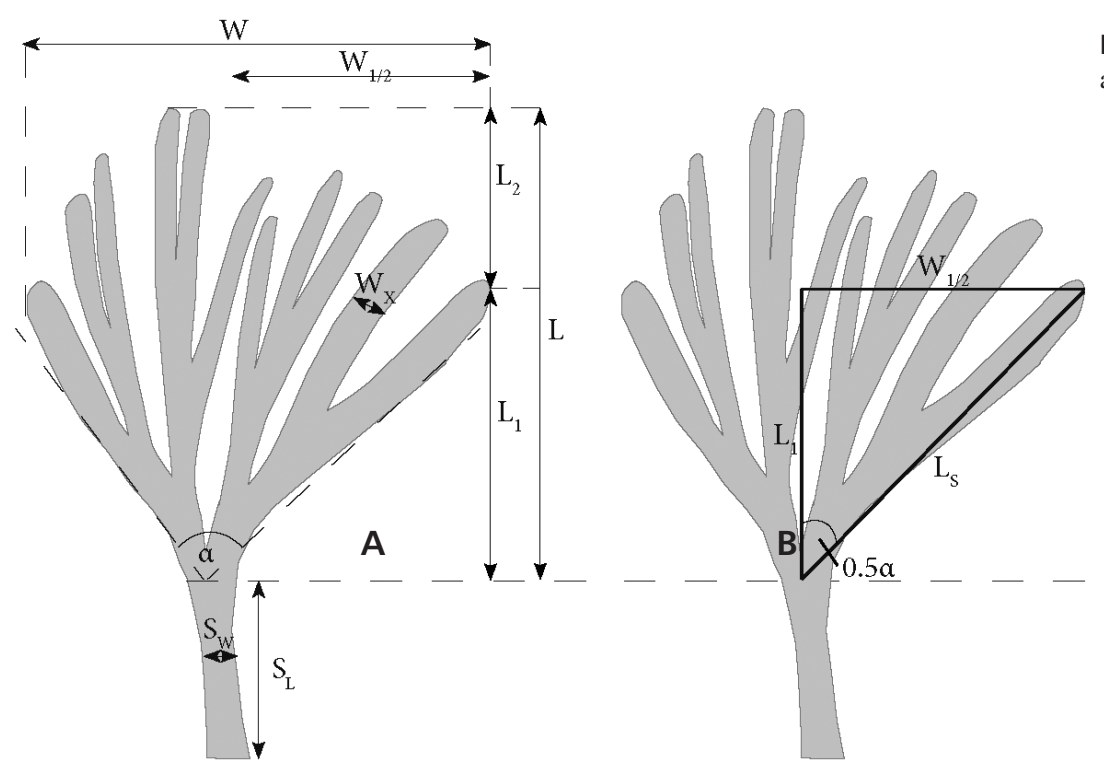

Figure 2. Measurements of ginkgophyte leaves (A) and trigonometrical analyses (B).

euxinic depositional conditions the sediments became an important fossil Konservatlagerstätte (Bachmann 2008b). Fishes (e.g., Palaeoniscum freieslebeni Blainville, 1818) and vertebrates, including Coelurosauravus (Weigeltisaurus) jaekeli Weigelt, 1930 and Protorosaurus speneri Meyer, 1832, as well as plant remains and various invertebrates (e.g., bryozoans, gastropods, cephalopods, corals; Haubold \& Schaumberg 1985, Bachmann 2008b, Paul 2006) have been reported from these deposits.

\section{Material and methods}

During the first half of the $20^{\text {th }}$ century Johannes Weigelt studied the plant fossils from the Mansfeld Kupferschiefer and surrounding areas (Saxony-Anhalt) that were (and still are) housed in the collections of the Martin-Luther Universität at Halle-Wittenberg (Weigelt 1928, 1930, 1931, 1932), one of the most important collections for plant fossils from the German Kupferschiefer (Hauschke 2002). Other collections from the Mansfeld and Sangerhausen area are housed at the Technische Universität (TU) Bergakademie Freiberg and the Humboldt Museum für Naturkunde in Berlin, as well as at the Senckenberg Natural History Collections in Dresden and the Museum of the Geoscience Centre of the University of Göttingen. Plant fossils from the Thuringian Kupferschiefer (surrounding areas of Gera, Thuringia) are housed at the Museum für Naturkunde, Gera. For the present study, we analyzed a total of 103 ginkgophyte specimens from these collections.

Abbreviations. - MB.PB. - Humboldt Museum für Naturkunde, Berlin; MLU and Me - Institut für Geowissenschaften, Martin-Luther-Universität Halle-Wittenberg, Halle (Saale; Saxony-Anhalt, Germany); FG and P - Palaeontological and stratigraphical collection of the TU Bergakademie
Freiberg (Saxony, Germany); D-EP-S - Lithothek Reiche Zeche, TU Bergakademie Freiberg (Saxony, Germany); GZG.PB - Museum of the Geoscience Centre of the University of Göttingen; AnP - Senckenberg Natural History Collections Dresden; MfNG - Museum für Naturkunde, Gera.

The fossils are preserved as compressions; nevertheless, cuticles cannot be obtained from the specimens because they are too strongly carbonised. Taxonomic identification therefore relies exclusively on macromorphology (see above). The dimensions of the leaves (see Fig. 2A) were measured with a digital calliper, the length of the petiole $\left(\mathrm{S}_{\mathrm{L}}\right)$ up to the basis of the lamina, as well as the width of the widest part of the petiole $\left(\mathrm{S}_{\mathrm{W}}\right)$. The length of the lamina (L) was taken from the symmetry axis in the prolongation of the petiole (from the basis of the lamina to the apex of the longest segment), the width of the lamina (W) was measured at the widest part of the leaf. Moreover, the angle between the outer segments $(\alpha)$ with the derivation at the basis of the lamina was measured. For the morphometrical analyses the different measurements were divided against each other (see Table 1). The width of the lamina (exclusive petiole) was divided against the length of the lamina (W/L); the basal angle was divided against the length of the lamina $(\alpha / \mathrm{L})$ and the width of the lamina $(\alpha / \mathrm{W})$. Additionally, the width of the lamina segments was measured in the widest area to test as to whether this might be a useful parameter for the discrimination of leaf types. In many instances, the leaves are fragmentarily preserved, which obstructs, or even renders impossible, assignment to a particular genus or species. In these cases, we tested as to whether macromorphometry and trigonometrical analyses can help to reconstruct a general shape of the leaf that would then allow for safe determination. For this purpose, the distance from the base to the point of the greatest width of the lamina $\left(\mathrm{L}_{1}\right)$, or, if possible, the distance of the outer 
Table 1. Selected measurements and calculated ratios of Kupferschiefer ginkgophytes. Abbreviations: $\mathrm{S}_{\mathrm{L}}-$ length of petiole; $\mathrm{S}_{\mathrm{W}}-$ width of petiole; $\mathrm{L}$ - length of lamina exclusive petiole; $\mathrm{W}$ - width of lamina; $\alpha$ - angle between outer segments; $\alpha$-calc - calculated angle; $\mathrm{L}_{1}-$ distance from basis up to point of greatest width of lamina; $\mathrm{L}_{\mathrm{S}}$ - distance of outer segment up to point of greatest width of lamina; $\mathrm{W}_{\mathrm{x}}-$ segment width; n.m. - not measurable; n.c. - not calculable; LT - leaf type, only for Baiera digitata.

\begin{tabular}{|c|c|c|c|c|c|c|c|c|c|c|c|c|c|c|}
\hline Taxon & Number & Code & $\mathrm{L}$ & $\mathrm{L}_{1}$ & $\mathrm{~W}$ & $\alpha$ & $\alpha$-calc & SL & SW & $\mathrm{W} / \mathrm{L}$ & $\alpha / \mathrm{L}$ & $\alpha / \mathrm{W}$ & Wx & LT \\
\hline Baiera digitata & 461006 & MLU & 79.99 & 69.96 & 51.01 & 38 & 40 & 25.28 & 3.67 & 0.6 & 0.5 & 0.7 & $2.4-5.7$ & A \\
\hline Baiera digitata & $2008 / 96$ & MB.PB & 62.02 & n.m. & 61.55 & 87 & n.c. & 19.27 & 4.1 & 0.99 & 1.4 & 1.4 & $2.8-4$ & B \\
\hline Baiera digitata & $1799 / 2004$ & FG & 44.6 & 37.5 & 40 & 58 & 56.1 & 3.16 & 2.68 & 0.9 & 1.3 & 1.5 & $2-2.5$ & B \\
\hline Baiera digitata & $335 / 2002$ & FG & 49.7 & n.m. & 31.63 & 51 & n.c. & n.m. & n.m. & 0.6 & 1.03 & 1.6 & $1.5-3$ & B \\
\hline Baiera digitata & unlabeled & MLU & 44.42 & 28.72 & 33.18 & 61 & 60 & 13.89 & 4.92 & 0.75 & 1.4 & 1.8 & $2-2.5$ & B \\
\hline Baiera digitata & 59 & $\mathrm{Me}$ & 49.75 & n.m. & 39.99 & 45 & n.c. & 25.78 & n.m. & 0.8 & 0.9 & 1.1 & $1.2-1.8$ & B \\
\hline Baiera digitata & $1981 / 227$ & MB.PB & 64.08 & 38.3 & 59 & 77 & 75.2 & 21.76 & 3.95 & 0.9 & 1.2 & 1.3 & $3.5-3.7$ & B \\
\hline Baiera digitata & $1981 / 228$ & MB.PB & 63.33 & 48.33 & n.m. & 47 & n.c. & 13.25 & 5.78 & n.c. & 0.7 & n.c. & $3.7-6.7$ & A \\
\hline Baiera digitata & 2008/97 & MB.PB & 23.04 & 13.73 & 28 & 90 & 91.1 & 8.33 & 3.47 & 1.2 & 3.9 & 3.2 & $4.2-5.9$ & A \\
\hline Baiera digitata & $2008 / 141$ & MB.PB & 57.63 & 49.47 & 32.72 & 37 & 36.6 & n.m. & n.m. & 0.6 & 0.6 & 1.1 & $4.5-6$ & B \\
\hline Baiera digitata & $2872 / 2004$ & FG & 40.5 & n.m. & 31 & 32 & n.c. & 19.97 & 2.54 & 0.7 & 0.9 & 1 & $5.3-5.8$ & A \\
\hline Baiera digitata & $2008 / 81$ & MB.PB & 111.69 & n.m. & n.m. & 52 & n.c. & 19.85 & 4.04 & n.c. & 0.5 & n.c. & $2-3.5$ & B \\
\hline Baiera digitata & 2008/99 & MB.PB & 47.39 & n.m. & 39.97 & 38 & n.c. & 18.58 & 3.41 & 0.8 & 0.8 & 0.95 & $2-2.5$ & A \\
\hline Baiera digitata & 47603 & D-EP-S & 43.68 & 30 & 34 & 61 & 59 & n.m. & n.m. & 0.8 & 1.4 & 1.8 & 2.2 & B \\
\hline Baiera digitata & 50304 & D-EP-S & 97.86 & n.m. & n.m. & 40 & n.c. & n.m. & n.m. & n.c. & 0.4 & n.c. & $3.7-4.2$ & B \\
\hline Baiera digitata & 03/2012 & FG & 36.39 & n.m. & 30.81 & 51 & n.c. & 26.33 & 2.95 & 0.8 & 1.4 & 1.65 & 2.05 & B \\
\hline Baiera digitata & $2863 / 2004$ & FG & 33.25 & n.m. & 29.24 & 48 & n.c. & 23.24 & 3.73 & 0.9 & 1.4 & 1.6 & $1.9-3$ & B \\
\hline Baiera digitata & 5240 & GZG.PB. & n.m. & n.m. & 48.5 & 70 & n.c. & 11 & 3.9 & n.c. & n.c. & 1.4 & $1.8-3$ & B \\
\hline Esterella gracilis & 63 & AnP & $60-70$ & n.m. & 30 & n.m. & n.c. & n.m. & n.m. & $0.4-0.5$ & n.c. & n.c. & 2 & \\
\hline Esterella gracilis & $02 / 2012$ & FG & 77.52 & n.m. & 134.52 & 60 & n.c. & 43.81 & 3.73 & 1.7 & 0.8 & 0.45 & 1.5 & \\
\hline Esterella gracilis & 462204 & MLU & 106.51 & n.m. & 120.77 & 43 & n.c. & 14.49 & 5.3 & 1.1 & 0.4 & 0.4 & $2.65-3$ & \\
\hline Esterella gracilis & 1435 & MfNG & 90 & n.m. & 60 & n.m. & n.c. & n.m. & n.m. & 0.6 & n.c. & n.c. & $2.2-3$ & \\
\hline Esterella gracilis & 2008/84 & MB.PB & 79.14 & n.m. & 63.38 & 36 & n.c. & n.m. & n.m. & 0.8 & 0.45 & 0.6 & 1.8 & \\
\hline Baiera mansfeldensis & 47600 & D-EP-S & 64.22 & n.m. & 32.78 & 34 & n.c. & 19.72 & 3.42 & 0.5 & 0.5 & 1.03 & $3.5-9.3$ & \\
\hline Baiera mansfeldensis & $2008 / 137$ & MB.PB & 71.69 & n.m. & 20.46 & 18 & n.c. & 34.11 & 2.45 & 0.3 & 0.25 & 0.9 & $5.6-4.8$ & \\
\hline Baiera mansfeldensis & 462777 & MLU & 127.17 & n.m. & 22.9 & 15 & n.c. & n.m. & n.m. & 0.2 & 0.1 & 0.65 & 10.6 & \\
\hline Baiera mansfeldensis & 463034 & MLU & 57.31 & n.m. & n.m. & 30 & n.c. & n.m. & n.m. & n.c. & 0.5 & n.c. & $3.2-5.9$ & \\
\hline
\end{tabular}

segment to the point of the greatest width of the lamina $\left(\mathrm{L}_{\mathrm{S}}\right)$ were measured. An overall triangular shape of the ginkgophyte leaf is assumed (see Fig. 2B) and, therefore, from a combination of the lamina width or the basal angle, the missing parameters can be calculated with the following formulas: $\tan (0.5 \alpha)=0.5 \mathrm{~W} / \mathrm{L}_{1} ; \sin (0.5 \alpha)=0.5 \mathrm{~W} / \mathrm{L}_{\mathrm{S}}$ or $\cos (0.5 \alpha)=\mathrm{L}_{1} / \mathrm{L}_{\mathrm{S}}$. However, it is very important to take exact measurements because otherwise this method only produces approximations. Images of the fossils were captured with Canon EOS 450D and EOS 550D digital cameras following the procedures outlined in Kerp \& Bomfleur (2011).

\section{Systematic palaeobotany}

\section{Genus Baiera Braun, 1843 emend. Florin, 1936}

Type species. - Baiera muensteriana (Presley) Heer, 1876.
Baiera digitata (Brongniart) Heer, 1876

Figures 3, 4A-G, 5A-C

1828 Fucoides digitatis Brongniart, p. 69, pl. 9, fig. 1.

1862 Zonarites digitatus Brongniart. - Geinitz, p. 336, pl. 26, figs 1-3.

1876 Baiera digitata Brongniart. - Heer, p. 7, pl. 21, fig. 1. 1908 Baiera digitata (Brongniart) Heer. - Sellards, p. 460.

1909 Baiera digitata (Brongniart) Heer. - Tuzson, p. 35.

1928 Baiera digitata Brongniart. - Weigelt, p. 476, pl. 11, figs 1, 4; pl. 12, fig. 2.

1930 Baiera digitata (Brongniart) Heer. - Zimmermann, p. 361.

1936 Sphenobaiera digitata, Florin, p. 108.

1960 Sphenobaiera digitata (Brongniart) Florin. - Schweitzer, p. 11 , pl. 2, fig. 2 .

1958 Sphenobaiera digitata (Brongniart) Florin. - Stoneley, p. 319, text-fig. 10. 


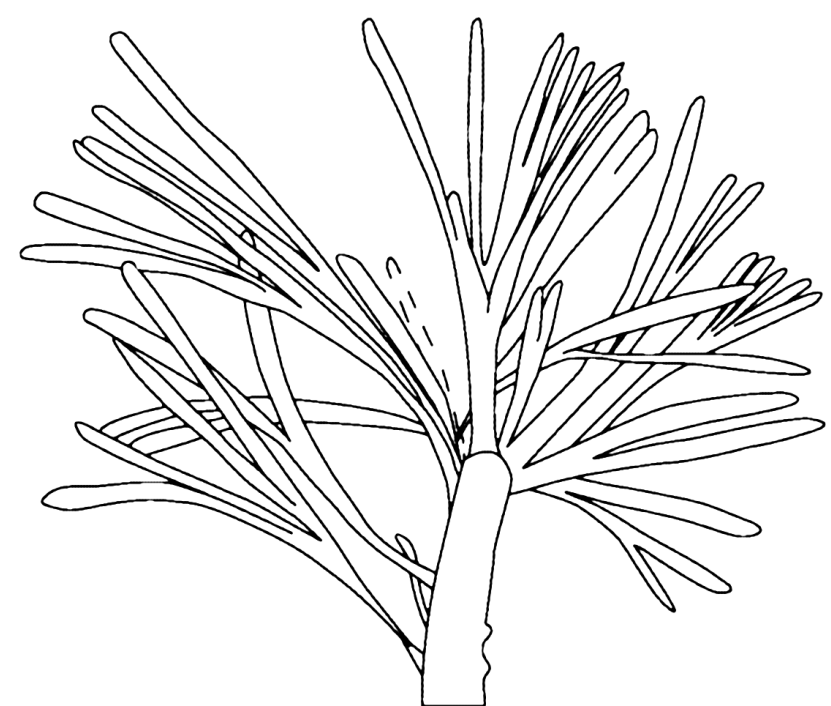

Figure 3. Baiera digitata (Brongniart) Heer, 1876; schematic drawing of shoot fragment from Halle-Wittenberg collection (Me 59; Eisleben).

1961 Baiera digitata (Brongniart) Heer. - Greguss, p. 139, pl. 61, fig. 12.

1980 Sphenobaiera digitata (Brongniart) Florin. - Daber, p. 268, text-figs 101-102.

1985 Sphenobaiera digitata (Brongniart) Florin. - Haubold \& Schaumberg, p. 86, text-fig. 44.

2005 Sphenobaiera digitata (Brongniart) Florin. - Hrouda \& Brandt, p. 150 , text-fig. 6 .

Neotype. - MB.PB.2008/96 (Fig. 4C), Humboldt Museum für Naturkunde in Berlin.

Comment. - A neotype has been designated because the holoptype is lost. MB.PB.2008/96 has been selected because it is very similar to the holotype specimen. Moreover, it is coeval (Kupferschiefer) and comes from the same area (Mansfeld) as the original specimen figured by Brongniart (1828).

Description. - The leaves are 30-152 mm long and characterized by a wedge-shaped lamina that is $23-120 \mathrm{~mm}$ long and $18-80 \mathrm{~mm}$ wide, meaning that the leaf is in most instances distinctly longer than wide $(\mathrm{W} / \mathrm{L}<1)$. The petiole is $4-40 \mathrm{~mm}$ long and $3-6 \mathrm{~mm}$ wide, and the lamina is subdivided into at least two symmetrical segments, each up to $11.6 \mathrm{~mm}$ wide. The dichotomous branching is regular, i.e. the individual lamina segments each fork at approximately the same distance from the base. Segments are linear (e.g., MLU 461006; Fig. 4A), elliptical (e.g., FG 2872/2004; Fig. 4B) or slightly wedge-shaped (e.g., MB.PB. 2008/96; Fig. 4C) and have a somewhat convex apex. The basal angle between the outer segments may reach $90^{\circ}$, but usually is between $40^{\circ}$ and $65^{\circ}$, and thus the $\alpha / \mathrm{L}: \alpha / \mathrm{W}$ ratio consistently is $<2$, which means that the basal angle is at maximum twice as wide as the length or width of the lamina. Because of the preservation, the venation is not recognizable; cuticles cannot not be obtained.

Two morphotypes are distinguished within the Kupferschiefer specimens of B. digitata based on morphometry: Type A is characterized by wedge-shaped or distally broadened segments (e.g., MB.PB. 1981/228, 2008/97; Fig. 4D, F). The lamina is somewhat smaller (up to $80 \mathrm{~mm}$ in length, $58 \mathrm{~mm}$ in width) than that of type B (i.e. up to $114 \mathrm{~mm}$ long and $79 \mathrm{~mm}$ wide). The $\mathrm{W} / \mathrm{L}$ ratio is $0.6-1.2, \alpha / \mathrm{W} 0.7-3.2$, and $\alpha / \mathrm{L} \quad 0.5-3.9$; within a given specimen, all three ratios are either $<1$ or $>1$. Type $\mathrm{B}$ leaves are characterized by linear segments (e.g., MLU 461006; FG 05/2012; D-EP-S 50304; Fig. 4A, F-G; Fig. 5B). The basal angle usually is $<87^{\circ}$, and thus is in most cases wider than the basal angle in type A leaves $\left(<90^{\circ}\right.$, usually $\left.30-47^{\circ}\right)$. Moreover, in each type B specimen one of the three ratios (i.e. W/L, $\alpha / \mathrm{W}$, or $\alpha / \mathrm{L}$ ) differs clearly from the other two values.

One specimen from the collection of the Martin-Luther-Universität (MLU) consists of a portion of a shoot with at least ten closely spaced type B leaves in organic connection (Me 59; length $47.1 \mathrm{~mm}$, width $9.2 \mathrm{~mm}$; Figs 3, 5C). The shoot portion is $47 \mathrm{~mm}$ long and $9 \mathrm{~mm}$ wide. Unfortunately, the shoot is too small and ill-preserved to reveal whether it represents a long or short shoot. Each leaf is characterized by a wedge-shaped to triangular lamina up to $75.5 \mathrm{~mm}$ long and up to $40 \mathrm{~mm}$ wide that consists of 4 linear segments with slightly convex tips. The leaves are arranged into two symmetrical groups and show a regular bifurcation pattern. The basal angle of the leaves between the outer segments measures approximately $45^{\circ}$. The venation pattern is not recognizable. Another interesting specimen comes from the Senckenberg Natural History Collections at Dresden (AnP63; Fig. 5A). This fossil shows several petiolate leaves that are arranged in a way suggestive of attachment to a shoot. The shoot itself, however, is not preserved. The leaves undoubtedly also belong to $B$. digitata morphotype $\mathrm{B}$, having a wedge-shaped to triangular lamina that is $60-70 \mathrm{~mm}$ long and $\sim 30 \mathrm{~mm}$ wide. Due to the

Figure 4. A - Baiera digitata (Brongniart) Heer, 1876; leaf type B; MLU 461006; Eisleben. • B - Baiera digitata (Brongniart) Heer, 1876; leaf type A; FG 2872/2004; Eisleben. • C - Baiera digitata (Brongniart) Heer, 1876; neotype; leaf type B; MB.PB. 2008/96; Mansfeld). • D - Baiera digitata (Brongniart) Heer, 1876; leaf type A; MB.PB. 2008/97; Mansfeld. • E - Baiera digitata (Brongniart) Heer, 1876; leaf type B; GZG.PB. 5240; Eisleben. - F - Baiera digitata (Brongniart) Heer, 1876; leaf type A; MB.PB. 1981/228; Eisleben. • G - Baiera digitata (Brongniart) Heer, 1876; leaf type B; FG 05/2012; Eisleben. Scale bar $-1 \mathrm{~cm}$. 
Kathleen Bauer et al. • The ginkgophytes from the German Kupferschiefer (Permian)
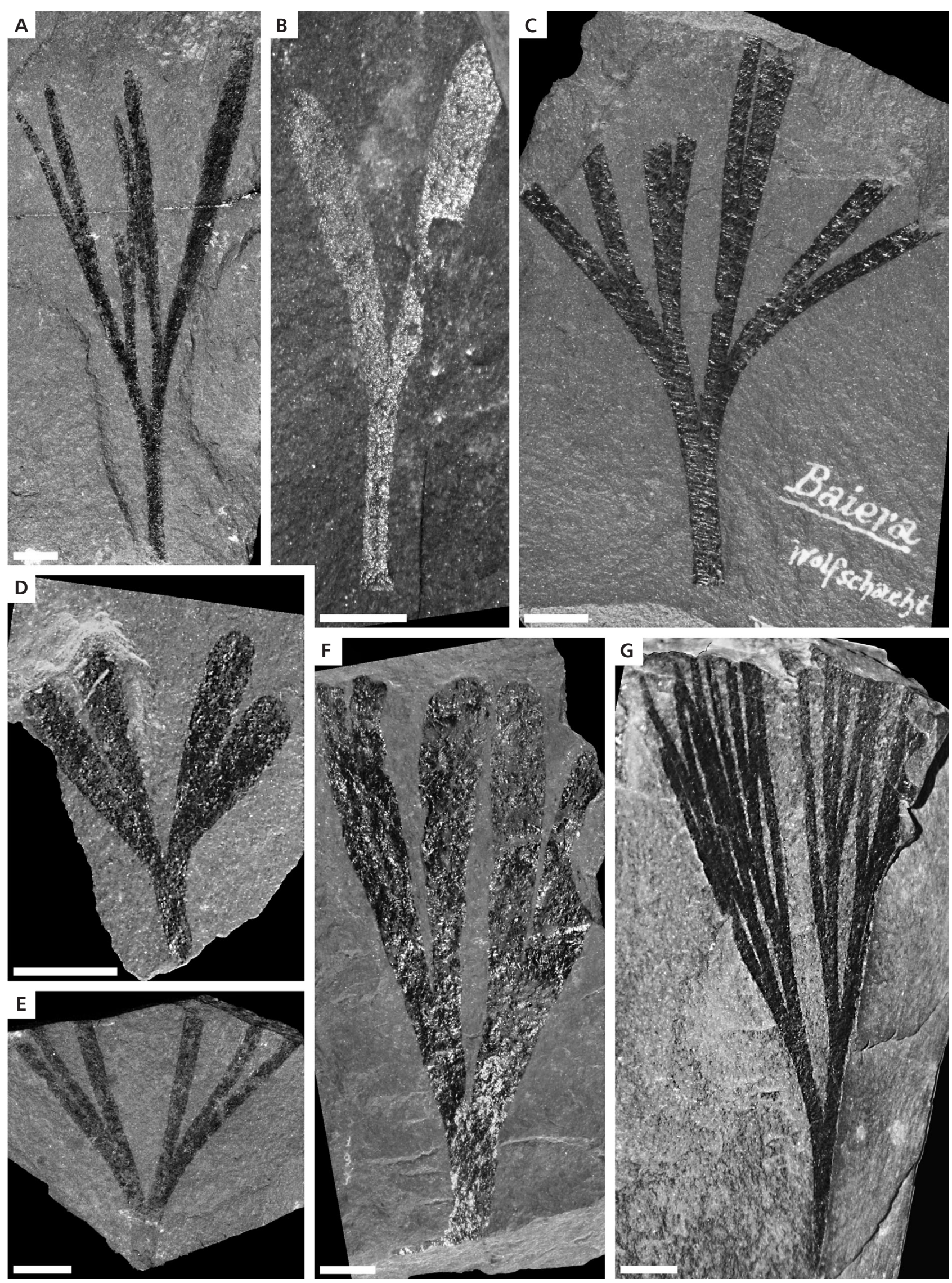
dense spacing of the leaves and the partial covering with sediment the basal angle cannot be determined. The venation pattern is not recognizable.

Remarks. - Florin (1936a, b) introduced the name Sphenobaiera for Baiera-like ginkgophyte leaves that lack a distinct petiole. However, no consensus exists regarding the generic attribution of the most common ginkgophyte foliage taxon in the late Permian Kupferschiefer flora from the Central European Basin. Some authors assign all specimens to Baiera digitata, while others refer to them as Sphenobaiera digitata, but without taking the absence or presence of a petiole into consideration (e.g., Haubold \& Schaumberg 1985). As a result, both names occur in the literature on the Kupferschiefer ginkgophytes, although none of the specimens in fact closely resembles the typical Sphenobaiera foliage as, for example, described by Barthel (2007) from the lower Permian of Thuringia (Germany). The absence of an axis-like petiole distinctly offset from the lamina can be used to separate Sphenobaiera from Baiera. Since a distinct petiole is present in all specimens from the Kupferschiefer flora displaying the basal portion of the leaf, we suggest that the name Baiera digitata should be used for these fossils, rather than Sphenobaiera digitata.

Within Baiera digitata from the German Kupferschiefer are two macromorphometrically different morphotypes: morphotype A is slightly smaller than type B and characterized by wedge-shaped to elliptical or inversely ovate segments, while type B has linear segments. It is possible that these differences lie within the natural intraspecific variability of $B$. digitata since a high intraspecific variability with regard to leaf size and morphology is also characteristic for the extant Ginkgo biloba (e.g., Kräusel 1917). If this is accurate, then the leaves with wedge-shaped segments perhaps were produced by younger plants, while leaves with linear segments belong to adult individuals (Seward 1919). On the other hand, the two leaf morphotypes may belong to different species. Arguing in favor of this hypothesis is perhaps the fact that leaves of younger $G$. biloba plants are typically more profoundly dissected than the leaves of adult plants (Seward 1919). Moreover, Heer (1876) included only leaves with linear segments in his emended diagnosis of $B$. digitata. In order to determine whether both leaf morphotypes belong to the same biological species, it would be necessary to study the epidermal anatomy from cuticles or discover a specimen that shows both leaf morphotypes attached to the same shoot.

Material. - FG 1224/1996, 335/2002, 1786/2004,
1799/2004, 2863/2004, 2869/2004, 2872/2004, 2873/2004, 03/2012, 04/2012, 05/2012; P1157; D-EP-S47603, 47606, 47607, 47608, 47612, 50304, 50305; MLU 461006; Me 59; Me 130; MB.PB. 1981/227, 1981/228, 1984/313, 1984/314, 1984/804, 2008/81, 2008/91, 2008/96, 2008/97, 2008/99. 2008/133, 2008/138, 2008/141, 2008/146, 2008/148, 2008/150, 2008/152; 1436, 4760; MfNG IX/IG2475; AnP 42, 58, 63, 79; GZG.PB 5240, 5253, two unnumbered specimens in the collection of the Martin-Luther-Universität Halle-Wittenberg.

Distribution. - Baiera digitata has been reported from the late Permian Kupferschiefer of Germany (Weigelt 1928, 1932; Schweitzer 1960) and the Marlslate of Middridge (Durham, England; Stoneley 1958), as well as the Permian of Hungary (Tuzson 1909, Greguss 1961, Heer 1876). The taxon has also been recorded for the late Palaeozoic of Kansas (North America; Sellards 1908).

\section{Baiera mansfeldensis sp. nov.} Figure 6A, B, D

1928 Baiera digitata Brongniart. - Weigelt, p. 476, pl. 11, figs 7, 19; pl. 30, fig. 18.

1932 Baiera digitata Brongniart. - Weigelt, p. 148, pl. 3, fig. 2.

1980 Sphenobaiera digitata (Brongniart) Florin. - Daber, p. 268 , text-fig. 101 .

Derivation of name. - After the locality Mansfeld in Germany from where the specimens were discovered.

Holotype. - MB.PB.2008/137, Humboldt Museum für Naturkunde in Berlin, here designated (Fig. 6A).

Type horizon. - Kupferschiefer, Wuchiapingian, upper Permian.

Type locality. - Wolfschacht, Mansfeld, Saxony-Anhalt, Germany.

Material. - D-EP-S 47600, 47605; MLU 462777, 463034, 463047; MB.PB. 2008/135, 2008/137; 1451.

Diagnosis. - Curved, broadly triangular leaf with bent petiole. All segments bent in one direction. Lamina distinctly longer than wide, $\mathrm{W} / \mathrm{L}$ ratio $<0.5$. Petiole long and slender, consistently thinner than lamina segments. Lamina subdi-

Figure 5. A - Baiera digitata (Brongniart) Heer, 1876; shoot fragment; AnP63; Eisleben. • B - Baiera digitata (Brongniart) Heer, 1876; leaf type B; D-EP-S 50304; Mansfeld. • C - Baiera digitata (Brongniart) Heer, 1876; shoot fragment; Me 59; Eisleben. Scale bar $-1 \mathrm{~cm}$. 
Kathleen Bauer et al. • The ginkgophytes from the German Kupferschiefer (Permian)
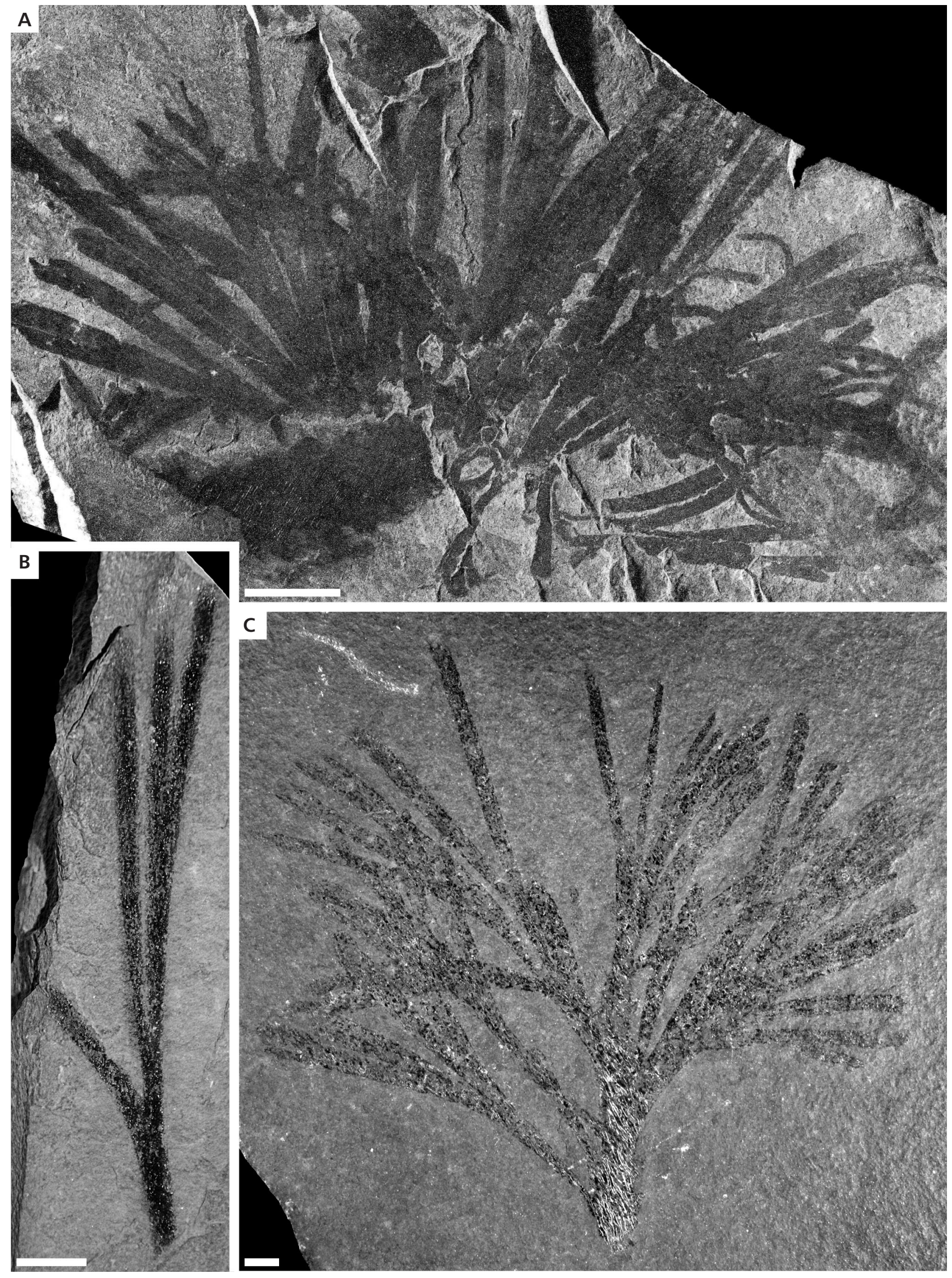
Table 2. Comparison of late Permian ginkgophytes.

\begin{tabular}{|c|c|c|c|c|c|c|c|c|}
\hline Taxon & Lamina & Petiole & $\begin{array}{l}\text { Number of } \\
\text { segments }\end{array}$ & Shape of segments & Apex & Basal angle & Branching & Veins \\
\hline Baiera digitata $\mathrm{A}$ & wedge-shaped & straight & $>2$ & $\begin{array}{l}\text { wedge-shaped, elliptical } \\
\text { or inversely lanceolate }\end{array}$ & rounded & $30-47^{\circ}$ & regular & not visible \\
\hline Baiera digitata $\mathrm{B}$ & wedge-shaped & straight & $>2$ & linear & rounded & $<87^{\circ}$ & regular & not visible \\
\hline Baiera mansfeldensis & broadly triangular & curved & $2(-4)$ & widening towards apex & rounded & $<35^{\circ}$ & regular & not visible \\
\hline Baiera plumosa & plume-like & $?$ & up to 24 & very fine and linear & $?$ & $?$ & $?$ & not visible \\
\hline Baiera virginiana & wedge-shaped & $?$ & numerous & linear & slightly rounded & $?$ & regular & several \\
\hline Baiera tartarica & wedge-shaped & $?$ & 6 & slightly bent and linear & slightly pointed & $50^{\circ}$ & regular & 8 per segment \\
\hline Baiera raymondii & wedge-shaped & straight & 16 & linear & rounded & $?$ & regular & numerous \\
\hline Esterella gracilis & $\begin{array}{l}\text { wedge- to } \\
\text { star-shaped }\end{array}$ & straight & up to 16 & $\begin{array}{l}\text { linear, progressive } \\
\text { degrease of width }\end{array}$ & rounded & $36-60^{\circ}$ & irregular & not visible \\
\hline
\end{tabular}

vided into at least two segments. Segments widening towards apex. Apex slightly convex. Basal angle $<35^{\circ}$.

Description. - The leaves are between 56-130 mm long and characterized by a curved lamina that is broadly triangular; all leaf segments are bent in one direction. The lamina is $48-127 \mathrm{~mm}$ long and $14-33 \mathrm{~mm}$ wide, which gives a $\mathrm{W} / \mathrm{L}$ ratio of $<0.5$. The petiole is axis-like, $7-34 \mathrm{~mm}$ long, and relatively narrow (less than $3.4 \mathrm{~mm}$ ), i.e. much thinner than the individual lamina segments (Fig. 6A). The lamina is subdivided into at least two segments. In one specimen (MLU 463034; Fig. 6D), at least three segments are present. Since the rest of the leaf is missing, the original number of segments of this leaf cannot be determined. However, it cannot be excluded that, in this taxon, the lamina can be subdivided more than once. Each segment is up to $8 \mathrm{~mm}$ wide and widened toward the rounded tip (Fig. 6B). The basal angle lies at less than $35^{\circ}$ with a ratio $\alpha / \mathrm{L}<0.5$, which results in an elongated and very narrowtriangular shape. The venation is not recognizable.

Comparison. - Baiera mansfeldensis differs from Baiera digitata in the shape of the lamina that is broadly triangular in B. mansfeldensis (Fig. 6A), but more or less wedgeshaped in B. digitata (Fig. 4A-G). The petiole of B. mansfeldensis is consistently thinner than the proximal segments, while in $B$. digitata the petiole is at least as thick as the segments itself. The basal angle in B. mansfeldensis is also much smaller $\left(<25^{\circ}\right)$ than in B. digitata $\left(>40^{\circ}\right)$. Moreover, the ratio between the width and length of the lamina are much smaller $(\mathrm{W} / \mathrm{L}<0.5)$ in the new taxon than in B. digitata, in which the width of the lamina reaches at least half the length (W/L > 0.5). Baiera mansfeldensis differs from Baiera plumosa Hoeg \& Bose, 1960 from the Permian of Kisulu (Luena, Democratic Republic of the Congo) with regard to segment number (i.e. up to 24 in B. plumosa). Moreover, the latter is more or less plumelike in shape. In Baiera virginiana Fontaine \& White, 1880 from the Permian of the Upper Barrens (West Virginia) the numerous segments fork again once or twice, while more than two bifurcations (Fig. 6D) have not been observed in B. mansfeldensis. Additionally, the lamina of B. virginiana is wedge-shaped in contrast to the broadly triangular B. mansfeldensis. Baiera tartarica Zalessky, 1929 from the Permian of the Republics Bachkire and Tatare (both Russia) has a much larger basal angle (i.e., 50 $)$ than B. mansfeldensis, and the segments fork more than once. This form also differs from $B$. mansfeldensis in the wedge-shaped lamina (broadly triangular in B. mansfeldensis). Baiera raymondii Renault, 1888 from the Permian of Charmoye (France) differs from B. mansfeldensis in its wedge-shaped lamina and different number of bifurcations (i.e., 16 secondary segments in $B$. raymondii). Moreover, the petiole of $B$. raymondii is as wide as the segments, while in $B$. mansfeldensis it is considerably thinner than the segments (Fig. 6A, B). Baiera leptophylla Harris, 1935 from the Rhaetian of Greenland differs from B. mansfeldensis by its widely triangular to wedge-shaped lamina. The segments fork repeatedly, which is not the case in B. mansfeldensis. At least 6 segments occur in B. leptophylla, while B. mansfeldensis has only 2(-4?). Baiera amalloidea Harris, 1935 from the Rhaetian of Greenland differs from B. mansfeldensis with regard to lamina shape (i.e. gradually widening towards the basis in B. amalloidea) and has segments that fork more often. Baiera simmondsii (Shirley) Seward, 1919 from the Rhaetian of Queensland (Australia) differs from B. mansfeldensis in the number of segments (up to 38 in B. simmondsii) and shape of the lamina, which is similar to that seen in leaves of the extant Ginkgo biloba. As a result, the basal angle of $B$. simmondsii is much wider $\left(>160^{\circ}\right.$ ) than in $B$. mansfeldensis. Additionally, the petiole is as wide as the lamina segments in B. simmondsii. Baiera geinitzii Nathorst, 1878 from the Rhaetian of Sweden differs from B. mansfeldensis in the shape of the lamina, which is subtriangular, whereas B. mansfeldensis is broadly triangular. Moreover, the B. geinitzii is characterized by 4-6 lamina segments, while B. mansfeldensis only has 2(-4?). Likewise, Baiera marginata Nathorst, 1878 from 
the Rhaetian of Sweden differs from B. mansfeldensis with regard to lamina shape, which is fan-shaped in the former taxon and has a larger number of segments (6-8). Baiera mansfeldensis differs from all other leave types currently accommodated in the genus Baiera in its curved petiole, which is consistently narrower than the basal segments. Moreover, all leaf segments are bent in one direction, which stands in contrast to the other forms, in which lamina and petiole are straight and the petiole is least as wide as the basal segments (see Table 2).

Remarks. - Most of the specimens assigned to Baiera mansfeldensis in this paper were initially referred to Baiera digitata (i.e. MB.PB. 2008/135, MLU 463034, Weigelt 1928; MB.PB. 2008/137, MLU 462777, Weigelt 1932) and later to Sphenobaiera digitata (Haubold \& Schaumberg 1985). The shape of the leaf, characterized by a conspicuously curved lamina and very narrow petiole, together with the completely different macromorphometric values, cannot be regarded as falling under the natural intraspecific variability of Baiera digitata. As a result, we propose that B. mansfeldensis represents a separate species, rather than simply another morphotype of $B$. digitata.

\section{Genus Esterella Boersma \& Visscher, 1969}

Type species. - Esterella gracilis Boersma \& Visscher, 1969.

\section{Esterella gracilis Boersma \& Visscher, 1969}

Figures 6C, E, 7

1928 Baiera digitata Brongniart, Weigelt, p. 476, pl. 12, 1, $7,11$.

1969 Esterella gracilis Boersma \& Visscher, p. 58, pl. 1, 1, pl. 2,1 .

1977 Trichopitys (al. Esterella) gracilis Boersma \& Visscher. - Remy \& Remy, p. 129, text-fig. 38.

Emended diagnosis. - (Modified after Boersma \& Visscher 1969.) Petiolate leaf (> $50 \mathrm{~mm}$ long) with wedgeshaped to palmate lamina. Petiole wider or as wide as base of lamina segments. Lamina repeatedly forked dichotomously; beginning with third order forking anisotomous. Individual lamina segments linear with rounded tip. Segments progressively decreasing in width towards leaf margin. Segments longitudinally striate (veins?).

Description. - The leaves are wedge-shaped (e.g., MLU 462204; Fig. 6E) to palmate (e.g., FG 02/2012; Fig. 6C) and $79-122 \mathrm{~mm}$ long. The lamina is at least $75-107 \mathrm{~mm}$ long and 55-135 $\mathrm{mm}$ wide, i.e. the lamina may be longer or shorter than wide $(\mathrm{W} / \mathrm{L}>1$ or $<1)$. The individual lamina segments are linear and have a slightly convex tip. The petiole (14-44 mm long and 3-6 mm wide) is at least as wide as but may also be wider than the proximal lamina segments (Fig. 6E). The proximal portion of the lamina is subdivided dichotomously into two segments, which may be as wide as the petiole, but higher-order segments are gradually becoming narrower (Fig. 6C). The second forking usually is dichotomous as well. Beginning with the third order forking, however, branching becomes more anisotomous. Segments may be subdivided into two parts, as is typical for ginkgophytes, but there are also segments that do not show further division. In the proximal portion of the leaf, the outer lamina segments fork at angles between 36 and $60^{\circ}$, and the ratio $\alpha / \mathrm{L}$ lies between 0.4 and 0.8 . The ratio $\alpha / \mathrm{W}$ is between $0.4-0.6$. The venation pattern and a distinctly striate surface, two features that have been reported from the material from France (Boersma \& Visscher 1969), are not recognizable in our specimens.

One of the specimens at hand (MfNG 1435; Fig. 7) consists of two wedge-shaped leaves (lamina up to $90 \mathrm{~mm}$ long and $60 \mathrm{~mm}$ wide) that apparently are attached to the same axis (not preserved) at angles of $\sim 45-50^{\circ}$. Both leaves are characterized by irregular forking. The segments are at maximum $1 \mathrm{~mm}$ wide and slightly tapering towards the tip. One of the leaves is characterized by $>22$ ultimate lamina segments.

Remarks. - Boersma \& Visscher (1969) describe two specimens of Esterella gracilis from the late Permian of southern France. According to these authors, the systematic position of Esterella remains unclear, but since the first two forkings of the lamina are dichotomous, they suggest that the affinities of these leaves probably lie with the ginkgophytes. Based on morphological features, including the small width of the lamina segments, presence of multiple, dichotomous forkings, and insertion to the axis at angles of $\sim 45^{\circ}$ (see specimen A in Boersma \& Visscher, 1969, pl. 2, fig. 3; MfNG 1435), Remy \& Remy (1977) affiliated E. gracilis with the genus Trichopitys. Trichopitys is an enigmatic fossil from the Carboniferous and early Permian that has been attributed to the ginkgophytes based primarily on the morphology of the female reproductive structures (Florin1949). However, fructifications or cuticles of the plant that would allow for a more precise assessment of the systematic position and relationships of E. gracilis have not been discovered to date. As a result, we retain E. gracilis in the genus Esterella.

Comparisons. - Esterella gracilis differs from all species accomodated in the genera Baiera and Sphenobaiera by its irregular forking pattern; the forkings of the lamina in Baiera and Sphenobaiera are quite regular. Esterella gracilis differs from T. heteromorpha Saporta, 1875 in the number of ultimate segments, i.e. 4-8 in T. heteromorpha and $>8$ in E. gracilis. Moreover, T. heteromorpha leaves are not 
subdivided into lamina and petiole, while a distinct petiole is present in E. gracilis.

Trichopitys heterophylla Saporta mentioned in Doubinger (1956) in her inventory of Carboniferous-Permian floras from France is probably a typographic error since, as far as we could ascertain, Saporta only introduced Trichopitys heteromorpha but not $T$. heterophylla. Trichopitys whitei Read, 1931 from the Pennsylvanian of Colorado differs because the segments are narrower at the base, expand rapidly toward the apex, and fork once to form two unequal lobes. Trichopitys milleryensis Renault, 1896 from the Permian of France differs from E. gracilis in the number of ultimate segments (up to 10 in $\mathrm{T}$. milleryensis). Moreover, the tapering of the segment tips is more prominent than in E. gracilis.

Material. - FG 02/2012; MLU 462105, 462204, 462288; MB.PB. 2008/84; 1435; AnP 65.

Distribution. - Esterella gracilis has been recorded for the late Permian of southern France (Boersma \& Visscher 1969) and the Kupferschiefer (late Permian) of Germany (this paper).

\section{Discussion}

The origin and diversification of the ginkgophytes during the late Palaeozoic continues to be incompletely understood. The oldest fossils variously speculated to represent ginkgophytes or ginkgophyte precursors include the foliage taxa Ginkgophytopsis Høeg, 1967 (Permo-Carboniferous of Eurasia; Gothan \& Kukuk 1933, Zhou 2007) and Ginkgophyllum Saporta, 1875 (Permo-Carboniferous of Eurasia, Zhou 2007; Middle Permian of China, Yao 1989). However, virtually nothing is known to date about the parent plants, and consequently these leaf types have also been discussed as belonging to other plant groups such as the ferns, seed ferns, tree ferns or even cordaites (Taylor et al. 2009). The morphology and growth habit of Dicranophyllum Grand'Eury, 1877 (Pennsylvanian-Cisuralian of Germany; Barthel 1977) are well-understood based on large specimens from the Rotliegend of SW Germany (early Permian; Remy \& Remy 1959, Barthel \& Noll 1999, Barthel 2007). Barthel \& Noll (1999) interpret this taxon as a conifer, but others have also assigned it to the ginkgophytes (e.g., Němejc 1959). More clarity exists regarding Trichopitys Saporta, 1875 (early Permian of Lodève, southern France; Florin 1949, Taylor et al. 2009) and Polyspermophyllum Archangelsky \& Cúneo, 1990 (early Permian of Argentina; Taylor et al. 2009), which are generally viewed as representing primitive ginkgophytes (Archangelsky \& Cúneo 1990). Florin (1949) considered Trichopitys as a putative sister group to all Mesozoic ginkgoaleans.
According to Zhou \& Wu (2006) the radiation of the ginkgophytes started during the Middle Triassic, and the group reached its peak diversity during the Late Triassic, with 12 genera in 6 families. Moreover, these authors state that the Middle Triassic ginkgophyte radiation was characterized by the establishment of important innovations within this lineage, including short-shoots and the differentiation of the leaves into lamina and petiole. Our re-examination of the Kupferschiefer ginkgophytes from Germany presented in this paper provides evidence indicating that petiolate leaves were present in ginkgophytes already during the late Permian. Unfortunately, too few shoot fragments are currently available to determine as to whether some Permian ginkgophytes may already have evolved dwarf shoots.

One bona fide ginkgophyte genus (i.e., Baiera) has been documented from the late Permian Kupferschiefer flora of Germany. Together with the Sphenobaiera-type leaves from the lower Permian of Germany (Barthel 2007) and Antarctica (Taylor \& Taylor 1993), Kerpia-like leaves from the Permian of Angara (Naugolnykh 2007) and Ginkgoites-type leaves of India, Argentina, South-Africa and the Congo, at least four distinct foliage genera of indisputable ginkgophytes are present in the Permian worldwide. Moreover, several other Permian taxa have been described with possible affinities in the ginkgophytes, including Polyspermophyllum (e.g., Plumstead 1961, Dijkstra 1973, Bajpai 1991, Naugolnykh 2007), Trichopitys (Saporta 1875), Ginkgophyllum (Zalessky 1912), Meristophyllum (Zalessky 1937) or Dicranophyllum (e.g., Gothan \& Kukuk 1933, Barthel 1977). This may suggest that a first diversification of the ginkgophytes occurred during the Permian and not, as previously believed, during the Triassic. It is also interesting to note that all bona fide ginkgophyte genera from the Permian survived the end-Permian mass extinction and persisted into the Middle and Late Triassic.

It has been assumed that the intraspecific leaf size and shape variability in fossil ginkgophytes is similar to that seen in the extant Ginkgo biloba. Our macromorphometrical analysis reveals that at least two (B. digitata, B. mansfeldensis) or perhaps even three (if the two morphotypes of $B$. digitata represent separate taxa) different Baiera species occurred in the German Kupferschiefer flora, together with one putative ginkgophyte, Esterella gracilis. Moreover, there appears to be a trend with regard to the ratios within all three taxa: W/L is mostly $<1$, which means that the lamina of the Baiera and Esterella leaves is longer than wide. $\alpha / \mathrm{L}$ and $\alpha / \mathrm{W}$ are always $<2$, which means that the basal angle is at best twice as high as the length or width of the lamina. The close values of these three ratios might reflect the degree of natural variability within Permian ginkgophyte foliage. With the help of trigonometrical analyses, even if only fragments of the leaves are preserved, the theoretical maximum 

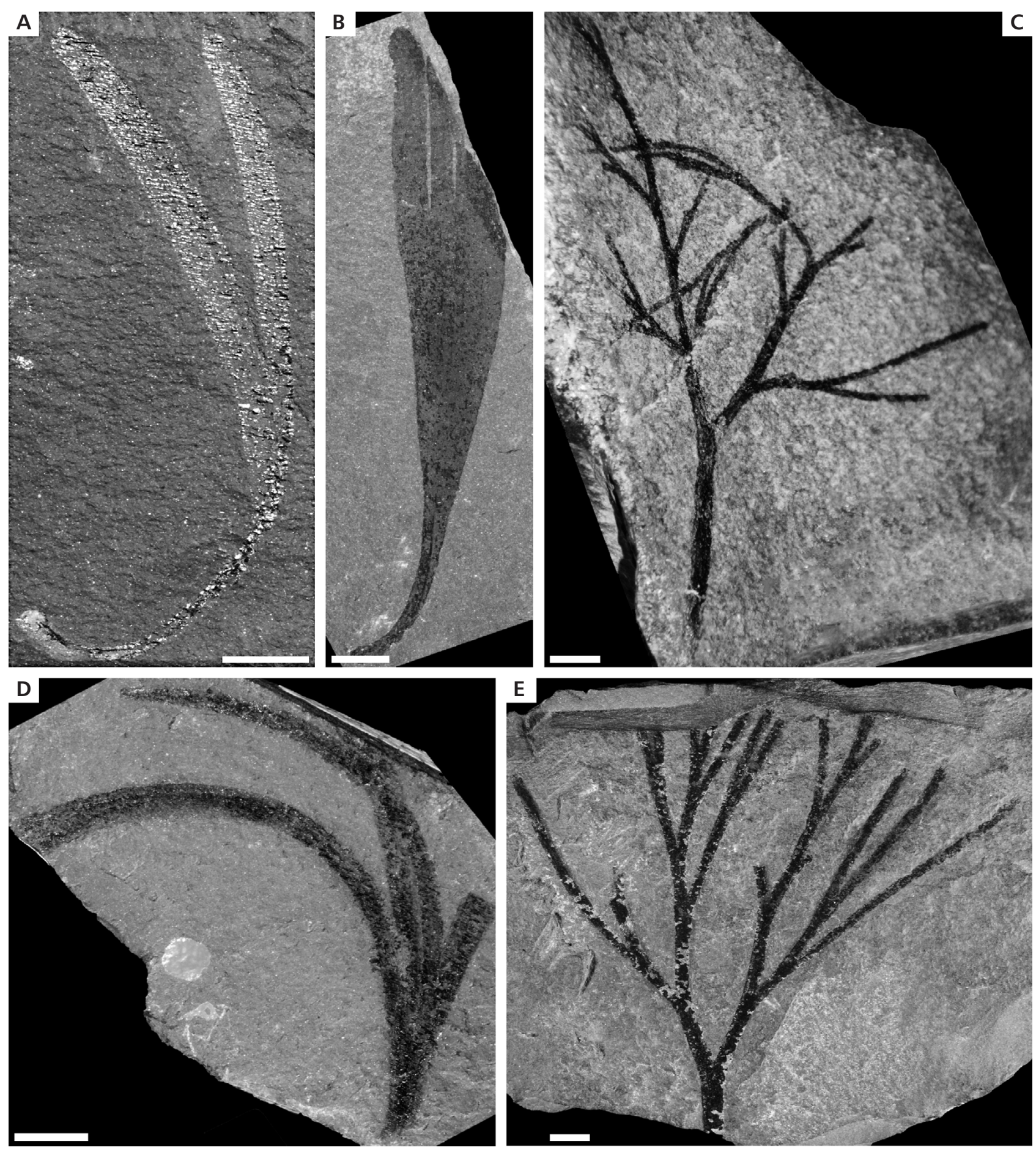

Figure 6. A - Baiera mansfeldensis sp. nov.; holotype; MB.PB. 2008/137; Mansfeld. • B - Baiera mansfeldensis sp. nov.; MLU 462777; Eisleben. - C - Esterella gracilis (Boersma \& Visscher, 1969) Remy \& Remy, 1977; FG 02/2012; Eisleben. • D - Baiera mansfeldensis sp. nov.; MLU 463034; Mansfeld. • E - Esterella gracilis (Boersma \& Visscher, 1969) Remy \& Remy, 1977; MLU 462204; Eisleben. Scale bar $-1 \mathrm{~cm}$.

of the length, width, or the basal angle of a leaf fragment can be calculated. Additionally, it is possible to create an image of the shape of the lamina by using trigonometrical analyses. Other measurements such as the width of the segments seem to be more or less taxon independent.
With the exception of E. gracilis, in which the ultimate segments are narrower than the proximal ones, a distinct trend with regard to segment width is not recognizable.

Ginkgophyte leaves are often used for palaeoenvironmental and palaeoclimate reconstructions in the Mesozoic 


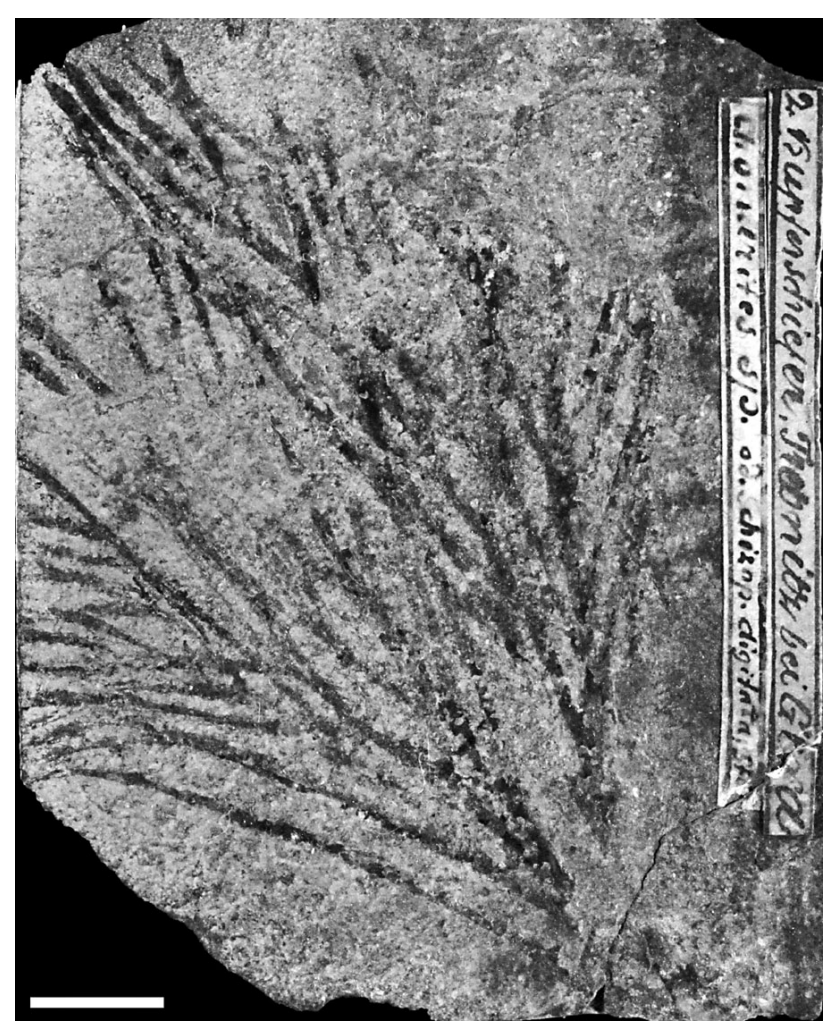

Figure 7. MfNG 1435: Esterella gracilis (Boersma \& Visscher, 1969) Remy \& Remy, 1977; Trebnitz. Scale bar $-1 \mathrm{~cm}$.

and Cenozoic; especially popular are stomatal index and isotope analyses (e.g., Chen et al. 2001, Royer et al. 2001, Retallack 2001, Beerling \& Royer 2002, Sun et al. 2003, Taylor et al. 2009). All these studies are based on the Nearest Living Relative (NLR) approach, which operates with the presumption that the climatic tolerance of a fossil taxon is similar to that of its NLR. This approach depends, however, on the ability to identify as accurately as possible the systematic affinities of fossils and understand their morphology, growth habit, as well as the conditions of the habitat(s) of growth. The optimum growing area of the extant $G$. biloba is characterized by mean temperatures of $10-18{ }^{\circ} \mathrm{C}$ and an annual mean precipitation of $600-1000 \mathrm{~mm}$, although in cultivation the climatic range is much higher (e.g., He et al. 1997, Zhou 2009). For the late Palaeozoic ginkgoaleans with non-petiolate leaves and lacking reduced vegetative shoots, a warm to hot, nearly uniform climate with long growing seasons has been proposed (Zhou 2009). The radiation of the ginkgophytes during the Triassic is believed to be related to the variable climate and the establishment of different environments following the end-Permian mass extinction (see also Ziegler et al. 1996, Zhou \& Wu 2006, Zhou 2009). It has been suggested that ginkgophytes during the Mesozoic thrived in stable environments (Zhou 1994, 1997), in warm to temperate and coastal humid to inland near-shore or ri- parian/swamps (see Zhou 2009, table 1), in the early Cretaceous (Wealden flora of England) in hot and warm coastal environments with long seasonal drought (Watson 1969, Watson \& Sincock 1992, Zhou 2009). On the other hand, during the late Cretaceous and Cenozoic these plants occurred in disturbed streamsides and levee environments (Ginkgo adiantoides; Royer et al. 2003). Zhou \& Wu (2006) suggested that the group did show a broad adaptability, with some forms that even grew in halophytic conditions (Kvaček et al. 2005). Nonetheless, ginkgophytes were more abundant and diversified in mesic, warm to temperate climates similar to the relictual area of their living representative G. biloba. During the Late Cretaceous and Early Palaeogene these plants in fact became an important component of the floras at high latitudes (Zhou 2009). However, the Kupferschiefer flora (late Permian) of Germany does not represent a low latitude flora. Moreover, arid conditions have been suggested for the Kupferschiefer that again changed during the Zechstein to more humid conditions (Grebe 1957, Daber 1960, Haubold \& Schaumberg 1985, Bechtel \& Püttmann 1997). As a result, the distribution and climatic adaptations of the ginkgophytes from the Kupferschiefer do not correspond to those of the Mesozoic ginkgophytes from Laurasia, and even less to G. biloba. Additionally, as pointed out by Preto et al. (2010, and references therein), the Middle and Late Triassic were characterized by humid periods such as the Carnian Pluvial Event, but not generally by a warm and humid climate.

\section{Summary}

Documented evidence of late Permian floras from Europe and North America is rare; the most important evidence comes from the Kupferschiefer of Germany (e.g., Mansfeld, Trebnitz/Gera, etc.). All ginkgophyte leaves from the German Kupfeschiefer have traditionally been assigned to Sphenobaiera/Baiera digitata, a taxon characterized by high intraspecific variability. Our re-analysis of the material from several historical Kupferschiefer localities indicates that the ginkgophytes are represented by two different representatives of the genus Baiera (B. digitata, B. mansfeldensis sp. nov.) and possibly Esterella gracilis.

While Baiera digitata is quite common in the Kupferschiefer, Baiera mansfeldensis and Esterella gracilis are rare elements of the flora. Our morphometrical analysis of the German Kupferschiefer ginkgophytes underscores the general value of this methodological approach in contributing to a more sharply focused concept of ancient floras and ecosystems. Since confusion still exists with regard to the use of the names Baiera and Sphenobaiera, many Permian and Triassic fossils assigned to these taxa are in need of 
revision. Some of them may belong to Baiera, rather than Sphenobaiera, based on the presence of a distinct petiole (e.g., Sphenobaiera raymondii from the Permian of France). Our results indicate that macromorphometry represents a useful tool for the discrimination of taxa if cuticles cannot be extracted and the specimens exhibit similar macromorphological features. In order to improve the method and to better understand the palaeodiversity of the ginkgophytes, this macromorphometry should be applied to a larger set of ginkgophyte foliage fossils, including $\mathrm{Me}$ sozoic and Cenozoic representatives. The method should also be used with fossils yielding cuticles, as for example those from the upper Permian of the Dolomites (Kustatscher et al. 2012) to compare the results of both approaches.

\section{Acknowledgements}

We thank Norbert Hauschke (Halle-Wittenberg), Stephan Schultka and Catrin Puffert (Berlin), Birgit Gaitzsch and Jörg W. Schneider (Freiberg), Lutz Kunzmann (Dresden), Frank Hrouda (Gera), and Mike Reich (Göttingen) for making the collections under their care available, for assistance during our visits, and for inspiring discussions. We thank Christian Pott (Stockholm) for help with literature, and Johanna H.A. Van Konijnenburg-van Cittert (Leiden and Utrecht) and Hans Kerp (Münster) for fruitful discussion. We are indebted to Gea Zijlstra for help with nomenclatural problems, and to Leyla Seyfullah (Göttingen) for manuscript proofreading. The manuscript greatly benefited from the critical remarks and comments of Zhiyan Zhou (Nanjing) and an anonymous referee. This paper is part of the project "The Permian-Triassic ecological crisis in the Dolomites: extinction and recovery dynamics in terrestrial ecosystems" funded by the Promotion of Educational Policies, University and Research Department of the Autonomous Province of Bolzano - South Tyrol. E.K. acknowledges financial support from the Alexander von Humboldt-Foundation.

\section{References}

Althaus, J. 1847. Ueber einige neue Pflanzen aus dem Kupferschiefer von Riechelsdorf. Palaeontographica 1, 30-33.

ArChangelsky, S. \& CúneO, R. 1990. Polyspermophyllum, a new Permian gymnosperm from Argentina, with considerations about the Dicranophyllales. Review of Palaeobotany and Palynology 63, 117-135. DOI 10.1016/0034-6667(90)90009-8

BachmanN, G.H. 2008a. 4.8 Perm, 4.8.1 Allgemeines, 140-143. In Bachmann, G.H., Ehling, B.-C., Eichner, R. \& Schwab, M. (eds) Geologie von Sachsen-Anhalt. E. Schweizerbart, Stuttgart.

Bachmann, G.H. 2008b. 4.14.4 Kupferschiefer (Oberes Perm), 329-330. In Bachmann, G.H., Ehling, B.-C., Eichner, R. \& Schwab, M. (eds) Geologie von Sachsen-Anhalt. E. Schweizerbart, Stuttgart.
BAJPAI, U. 1991. On Ginkgoites leaves from the early Permian of Rajmahal Hills, Bihar, India. Amegheniana 28, 145-148.

BARTHEL, M. 1977. Die Gattung Dicranophyllum Gr.'Eury in den varistischen Innensenken der DDR. Hallesches Jahrbuch für Geowissenschaften 2, 73-86.

BArthel, M. 2007. Die Rotliegendflora des Thüringer Waldes Teil 5: Ginkgophyten, Coniferophyten. Veröffentlichungen Naturhistorisches Museum Schleusingen 22, 41-67.

BARTHel, M. \& Noll, R. 1999. On the growth habit of Dicranophyllum hallei Remy et Remy. Veröffentlichungen des Naturhistorisches Museum Schleusingen 14, 59-64.

Bechtel, A. \& Püttmann, W. 1997. Palaeoceanography of the early Zechsteinsea during Kupferschiefer deposition in the Lower Rhine Basin (Germany): A reappraisal from stable isotope and organic geochemical investigations. Palaeogeography, Palaeoclimatology, Palaeoecology 136, 331-358. DOI 10.1016/S0031-0182(97)00104-1

BEERLING, D.J. \& RoYER, D.L. 2002. Reading a $\mathrm{CO}_{2}$ signal from fossil stomata. New Phytologist 153, 387-397. DOI 10.1046/j.0028-646X.2001.00335.X

Blainville, H.M.D. 1818. Poissons. Nouveau dictionnaire d'Histoire Naturelle 27, 310-395.

Boersma, M. \& Visscher, H. 1969. On two Late Permian Plants from southern France. Mededelingen Rijks Geologische Dienst, Nieuwe Serie 20, 57-63.

Braun, F.R. 1843. Beiträge zur Urgeschichte der Pflanzen. I. Die Fundorte von fossilen Pflanzen in der Umgegend von Bayreuth und Geschichte ihres Auffindens, 1-46. In MÜNSTER, G. Graf Zu (ed.) Beiträge zur Petrefacten-Kunde. Buchner'sche Buchhandlung, Bayreuth.

BRONGNIART, A. 1828. Histoire des végétaux fossiles, ou recherches botaniques et géologiques sur les végétaux renfermés dans les diverses couches du globe. 488 pp. Crochard et Comp., Paris.

Chen, L.Q., Li, C.S., Chaloner, W.G., BeErling, D.J., Sun, Q.S., Collinson, M.E. \& Mitchell, P.L. 2001. Assessing the potential for the stomatal characters of extant and fossil Ginkgo leaves to signal atmospheric $\mathrm{CO}_{2}$ change. American Journal of Botany 88, 1309-1315. DOI 10.2307/3558342

Cúneo, R. 1987. Sobre la presencia de probables Ginkgoales en el Permico inferior du Chubut, Argentina. Actas VII Simposio Argentino de Paleobotanica y Palinologia, Buenos Aires, 47-49.

DABER, R. 1960. Paläobotanische Bemerkungen zur Kupferschieferpaläogeographie. Geologie 9(8), 930-935.

DABER, R. 1980. 280 Millionen Jahre Ginkgo - Belegstücke zur Geschichte des Taxons Ginkgo L. aus den Sammlungen und Anlagen der Humboldt-Universität. 100 Jahre Arboretum, 259-279.

Dijkstra, S.J. 1973. Fossilium Catalogus. II. Plantae, pars 82. 116 pp. Kluwer Academic Publishers, s-Gravenhage.

Doornenbal, H. \& Stevenson, A. 2010. Petroleum Geological Atlas of the Southern Permian Basin Area. 354 pp. EAGE Publications BV, Houten.

Doubinger, J. 1956. Contribution à l'étude des flores AutunoStephaniennes. Mémoires de la Société Géologique de France 75, 1-180. 
FenG, Z., WANG, J. \& RößLER, R. 2010. Palaeoginkgoxylon zhoui, a new ginkgophyte wood from the Guadalupian (Permian) of China and its evolutionary implications. Review of Palaeobotany and Palynology 162, 146-158. DOI 10.1016/j.revpalbo.2010.06.010

FloRIN, R. 1936a. Die fossilen Ginkgophyten von Franz-JosephLand nebst Erörterungen über vermeintliche Cordaitales Mesozoischen Alters: I. Spezieller Teil. Palaeontographica B81(3-6), 71-173.

FloRIN, R. 1936b. Die fossilen Ginkgophyten von Franz-JosephLand nebst Erörterungen über vermeintliche Cordaitales Mesozoischen Alters: II. Allgemeiner Teil. Palaeontographica B81(3-6), 71-173.

FloRIN, R. 1949. The morphology of Trichopitys heteromorpha Saporta, a seed-plant of Palaeozoic age, and the evolution of the female flowers in the Ginkgoinae. Acta Horti Bergiani 15, 79-109.

Fontaine, M.A. \& White, A.M. 1880. The Permian or Upper Carboniferous flora of West Virginia. 143 pp. Second Geological Survey of Pennsylvania, Harrisburg.

DOI 10.5962/bhl.title.7587

FrentZen, K. 1922. Die Keuperflora Badens. Verhandlungen des naturwissenschaftlichen Vereins in Karlsruhe 28, 1-78.

GEINITZ, M.E. 1862. Dyas oder die Zechsteinformationen und das Rothliegende, Heft II: Die Pflanzen der Dyas und Geologisches, 132-342. Wilhelm Engelmann, Leipzig.

Germar, E.F. 1840. Die Versteinerungen des Mansfelder Kupferschiefers. 41 pp. Eduard Anton, Halle.

Gothan, W. \& Kukuk, P. 1933. Über das sogenannte "Psygmophyllum" delvali Cambier und Renier. Sitzungsberichte der Gesellschaft Naturforschender Freunde zu Berlin 1-3, 66-77.

Gothan, W. \& Nagelhard, K. 1921. Kupferschieferpflanzen aus dem niederrheinischen Zechstein. Sonderabdruck aus dem Jahrbuch der Preußischen Geologischen Landesanstalt 42(1), 440-460.

Grand'Eury, M.F.C. 1877. Mémoires sur la Flore Carbonifère du department de la Loire et du Centre de la France, étudée aux trois points de vue Botanique, Stratigraphique et Géognostique. 677 pp. Mémoires presents par divers savants a l'Académie des Sciences de l'Institut de France, Sciences Mathématiques et Physiques, Paris.

Grebe, H. 1957. Zur Mikroflora des niederrheinischen Zechsteins. Geologisches Jahrbuch 73, 51-74.

Greguss, P. 1961. Permische fossile Hölzer aus Ungarn. Palaeontographica B109, 131-146.

Halle, T.G. 1908. Zur Kenntnis der mesozoischen Equisetales Schwedens. Kungliga Svenska Vetenskapsakademiens Handlingar 43(1), 1-37.

HARRIS, T.M. 1935. The fossil flora of Scoresby Sound East Greenland, Part 4: Ginkgoales, Coniferales, Lycopodiales and isolated fructifications. 172 pp. C.A. Reitzels Forlag, København.

Harris, T.M. \& Millington, W. 1974. The Yorkshire Jurassic flora IV. 150 pp. Trustees of the British Museum (Natural History), London.
Haubold, H. \& Schaumberg, G. 1985. Die Fossilien des Kupferschiefers. 223 pp. Die Neue Brehm-Bücherei, Wittenberg.

HauschKe, N. 2002. 5.5 Die Geologisch-Paläontologischen Sammlungen, 122-130. In Görgner, E., HeidecKe, D., Klaus, D., Nicolai, B. \& Schneider, K. (eds) Kulturerbe Natur Naturkundliche Museen und Sammlungen in Sachsen-Anhalt. Mdv Mitteldeutscher Verlag, Halle.

HE, S.A., Gu, Y. \& PANG, Z.J. 1997. Resources and prospects of Ginkgo biloba in China, 373-383. In HoRI, T., Ridge, R.W., Tulecke, W., Del Tredici, P., Trémouillaux-Guiller, J. \& ToBe, H. (eds) Ginkgo biloba - A Global treasure from Biology to Medicine. Springer, Tokyo.

HeER, O. 1876. Über permische Pflanzen von Fünfkirchen in Ungarn. Mitteilungen aus dem Jahrbuch der königlich ungarischen geologischen Anstalt 5, 3-18.

HøEG, O.A. 1967. Ordre Incertae Sedis des Palaeophyllales, 362-399. In Boureau, E. (ed.) Traité de Paleobotanique 2. Briophyta, Psilophyta, Lycophyta. Masson et Cie, Paris.

HøEG, O.A. \& Bose, M.N. 1960. The Glossopteris Flora of the Belgian Congo. Annales du Musée Royal du Congo Belge 32, $1-107$.

Hrouda, F. \& BRAndT, S. 2005. Friedrich Eduard Mackroth (1807-1866) - Pionier der Zechstein-Forschung in Gera. Veröffentlichungen des Museums für Naturkunde Gera 32, 139-144.

Kerp, H. \& Bomfleur, B. 2011. Photography of plant fossils New techniques, old tricks. Review of Palaeobotany and Palynology 166, 117-151.

DOI 10.1016/j.revpalbo.2011.05.001

KILPPER, K. 1969. Nomina Conservanda II: Proposals on the conservation of generic names submitted to the eleventh International Botanical Congress, Seattle 1969. Baiera. Regnum Vegetabile 40, 30.

Kirchner, M. \& Van Konisnenburg-Van Cittert, J.H.A. 1994. Schmeissneria microstachys (Presl, 1833) Kirchner et Van Konijnenburg-van Cittert, sp. nov., plants with ginkgoalean affinities from the Liassic of Germany. Review of Palaeobotany and Palynology 83, 199-215. DOI 10.1016/0034-6667(94)90069-8

KRÄUSEL, R. 1917. Über die Variation der Blattform von Ginkgo biloba L. und ihre Bedeutung für die Paläobotanik. Centralblatt für Mineralogie 3, 63-68.

Kustatscher, E., VAn Koninnenburg-Van Cittert, J.H.A., Bauer, K., Butzmann, R., Meller, B. \& Fischer, T.C. 2012. A new flora from the upper Permian of Bletterbach (Dolomites, N-Italy). Review of Palaeobotany and Palynology 182, 1-13. DOI 10.1016/j.revpalbo.2012.06.001

Kvaček, J., Falcon-Lang, H.J. \& DašKovÁ, J. 2005. A new Late Cretaceous Ginkgolean reproductive structure Nehvizdyella gen. nov. from the Czech Republic and its whole-plant reconstruction. American Journal of Botany 92, 1958-1969. DOI 10.3732/ajb.92.12.1958

Langbein, R. \& Seidel, G. 2003. 4.4.2 Zechstein, 301-326. In SEIDEL, G. (ed.) Geologie von Thüringen. E. Schweizerbart'sche Verlagsbuchhandlung, Stuttgart.

MAHEShwARI, H.K. \& BAJPAI, U. 1992. Ginkgophyte leaves from 
the Permian Gondwana of the Rajmahal basin, India. Palaeontographica B 224, 131-149.

Meyen, S.V. 1988. Gymnosperms of the Angara flora, 338-381. In BECK, C.B. (ed.) Origin and Evolution of Gymnosperms. Columbia University Press, New York.

Meyer, H. von 1832. Palaeologica zur Geschichte der Erde und ihrer Geschöpfe. 560 pp. Siegmund Schmerber, Frankfurt.

NAthorst, A.G. 1878a. Beiträge zur fossilen Flora Schwedens. Über einige rhätische Pflanzen von Pålsjö in Schonen. 34 pp. Schweizerbart'sche Verlagsbuchhandlung, Stuttgart.

NAtHorst, A.G. 1878b. Bidrag till Sveriges fossila flora. II. Floran vid Höganäs och Helsingborg. 53 pp. Norsted \& Söner, Stockholm.

NaUgolnyKh, S.V. 2007. Foliar seed-bearing organs of Paleozoic ginkgophytes and the early evolution of the Ginkgoales. Paleontological Journal 41(8), 815-859.

DOI 10.1134/S0031030107080011

NĚMEJC, F. 1959. Notes on the evolution and taxonomy of the stachyospermic gymnosperms. Preslia 31, 251-272.

Paul, J. 2006. Der Kupferschiefer: Lithologie, Stratigraphie, Fazies und Metallogenese eines Schwarzschiefers. Zeitschrift der deutschen Gesellschaft für Geowissenschaften 157(1), 57-76. DOI 10.1127/1860-1804/2006/0157-0057

Plumstead, E.P. 1961. The Permo-Carboniferous coal measures of the Transvaal, South Africa - an example of the contrasting stratigraphy in the Southern and Northern Hemispheres. Quatrième Congrès International de Stratigraphie et de Géologie du Carbonifère 2, 545-550.

Preto, N., Kustatscher, E. \& Wignall, P.B. 2010. Triassic climates - State of the art and perspectives. Palaeogeography, Palaeoclimatology, Palaeoecology 290, 1-10. DOI 10.1016/j.palaeo.2010.03.015

RADZINSKI, K.-H. 2008. 4.8.3 Zechstein, 160-178. In BaCHMANN, G.H., Ehling, B.-C., Eichner, R. \& Schwab, M. (eds) Geologie von Sachsen-Anhalt. E. Schweizerbart, Stuttgart.

READ, C.B. 1931. A flora of Pottsville age from the Mosquito Range, Colorado. Geological Survey Professional Paper 185, 79-96.

Remy, R. \& Remy, W. 1959. Beiträge zur Kenntnis der Rotliegendflora Thüringens, Teil IV. Abhandlungen der Deutschen Akademie der Wissenschaften zu Berlin, Klasse für Chemie, Geologie und Biologie 2, 1-20.

Remy, W. \& Remy, R. 1977. Die Floren des Erdaltertums. 468 pp. Glückauf GmbH, Essen.

Renault, M.B. 1888. Les plantes fossiles. 399 pp. Librairie J.-B. Baillière et fils, Paris.

Renault, B. 1896. Études des Gîtes Minéraux de la France. Bassin Houiller et Permien d'Autun et d'Épinac. Fasicule IV. Flore Fossile, 2ième Partie. 578 pp. Imprimerie Nationale, Paris.

Retallack, G.J. 2001. A 300-million-year record of atmosphaeric carbon dioxide from fossil plant cuticles. Nature 411, 287-289. DOI 10.1038/35077041

Royer, D.L, Hickey, L.J. \& Wing, S.L. 2003. Ecological conservatism in the "living fossil" Ginkgo. Paleobiology 29, 84-104.

DOI 10.1666/0094-8373(2003)029<0084:ECITLF>2.0.CO;2
Royer, D.L., Wing, S.L., Beerling, D.J., Jolley, D.W., Кoch, P.L., Hickey, L.J. \& Berner, R.A. 2001. Paleobotanical evidence for near present-day levels of atmospheric $\mathrm{CO}_{2}$ during part of the Tertiary. Science 292, 2310-2313. DOI 10.1126/science.292.5525.2310

SAPORTA, G. 1875. Sur la découverte de deux nouveaux de Conifères dans les schistes permiens de Lodève (Hérault). Comptes Rendus hebdomadaires des Séances de l'Académie des Sciences 80, 1017-1022.

Schenk, A. 1867. Die fossile Flora der Grenzschichten des Keupers und Lias Frankens. 232 pp. Kreidel, Wiesbaden.

SCHIMPER, W.P. 1870. Traité de paléontologie végétale ou la flore du monde primitif. $966 \mathrm{pp}$. Baillière et fils, Paris.

Schmalhausen, J. 1879. Beiträge zur Jura-Flora Russlands. Mémore de l'Academie de Sciences St. Pétersbourg 27(4), $1-96$.

Schweitzer, H.-J. 1960. Die Makroflora des niederrheinischen Zechsteins. Fortschritte in der Geologie des Rheinlands und Westfalens 6, 331-376.

Schweitzer, H.-J. 1986. The land flora of the English and German Zechstein sequences, 31-54. In HARwoOD, G.M. \& SмiтH, D.B. (eds) The English Zechstein and related topics. Geological Society of London, Special Publication 22.

Sellards, E.H. 1908. Fossil plants of the Upper Paleozoic of Kansas. Kansas University Geological Survey 9, 386-467.

Seward, A.C. 1919. Fossil plants, IV Ginkgoales, Coniferales, Gnetales. 543 pp. Cambridge University Press, Cambridge.

Solms-Laubach, H. 1884. Die Coniferenformen des deutschen Kupferschiefers und Zechsteins. Paläontologische Abhandlungen 2(2), 19-26.

STERNBERG, G.K. 1825-1838. Versuch einer geognostischbotanischen Darstellung der Flora der Vorwelt. 80 pp. Prag.

Stoneley, H.M.M. 1958. The upper Permian flora of England. Bulletin of the British Museum (Natural History) 3(9), 295-337.

Sun, B., Dilcher, D.L., Beerling, D.J., Zhang, C., Yan, D. \& KowaLSKI, E. 2003. Variation in Ginkgo biloba L. leaf characters across a climatic gradient in China. Proceedings of the $\mathrm{Na}$ tional Academy of Sciences of the USA 100, 7141-7146. DOI 10.1073/pnas. 1232419100

TAYLOR, T.N. \& TAYLOR, E.L. 1993. The Biology and Evolution of Fossil Plants. 982 pp. Prentice Hall, New Jersey.

TAYlor, T.N., TAYlor, E.L. \& KRINGS, M. 2009. Paleobotany: The Biology and Evolution of fossil plants. 1230 pp. Elsevier, London.

Tuzson, J. 1909. Monographia der fossilen Pflanzenreste der Balatonseegegend. Resultate wissenschaftlicher Erforschung des Balatonsees 1, 1-60.

Watson, J. 1969. A revision of the English Wealden flora. I. Charales-Ginkgoales. Bulletin of the British Museum (Natural History), Geology 17, 207-264.

Watson, J. \& Sincock, C.A. 1992. Bennettitales of the English Wealden. Palaeontographical Society Monograph 145, 1-288.

Weigelt, J. 1928. Die Pflanzenreste des mitteldeutschen Kupferschiefers und ihre Einschaltung ins Sediment. Fortschritte der Geologie und Paläontologie 6(19), 422-592. 
Weigelt, J. 1930. Neue Pflanzenfunde aus dem Mansfelder Kupferschiefer. Leopoldina 4, 643-668.

Weigelt, J. 1931. Neue Pflanzenfunde aus dem Mansfelder Kupferschiefer. Zeitschrift für Naturwissenschaften 89, 104-125.

WeIgelt, J. 1932. Über Fruktifikationsverhältnisse von Kupferschiefer-Coniferen und andere neue Pflanzenfunde. Paläontologische Zeitschrift 14(3), 138-149.

YAo, Z.Q. 1989. Psygmophylloids of the Cathaysia Flora. Acta Paleontologica Sinica 28(2), 171-191. [in Chinese with English summary]

ZALESSKY, M.D. 1912. Observations sur l'extension d'une flore fossile voisine de celle de Gondwana dans la parte septentrionalis de L'Eurasie. Bulletin de la Société géologique de France 5(11), 109-129.

ZALESSKY, M. 1929. Sur des débris de nouvelles plantes Permiennes. Bulletin de l'Académie des Sciences de l'URS, 677-689.

ZaLESSKy, M.D. 1937. Sur la distinction de l'Étage Bardien dans le Permien de l'Oural et sur sa flore fossile. Problems of Paleontology 2-3, 37-101.

Zheng, S.L., Li, Y., Zhang, W., Li, N., Wang, Y.D., YAng, X.J., YI, T.M., YANG, J.J. \& Fu, X.P. 2008. Fossil Woods of China (English Edition). 356 pp. China Forestry Publishing House, Beijing.
Zноu, Z.Y. 1994. Heterochronic origin of Ginkgo biloba-type ovule organs. Acta Palaeontographica Sinica 33(2), 1-9. [in Chinese with English summary]

Zноu, Z.Y. 1997. Mesozoic ginkgoalean megafossils: a systematic review, 183-206. In Hori, T, Ridge, R.W., Tulecke, W., Del Tredici, P., TrémouillauX-Guiller, J. \& Tobe, H. (eds) Ginkgo biloba - A Global Treasure from Biology to Medicine. Springer Verlag, Toyo.

Zноu, Z.Y. 2007. Karkeiniaceae, Yimaiaceae, Umaltolepidaceae and Schmeissneriaceae. Strelitzia 20, 174-177.

Zноu, Z. 2009. An overview of fossil Ginkgoales. Palaeoworld 18, 1-22. DOI 10.1016/j.palwor.2009.01.001

Zноu, Z. \& Wu, X. 2006. The rise of ginkgoalean plants in the Early Mesozoic: A data analysis. Geological Journal 41, 363-375. DOI 10.1002/gj.1049

Ziegler, A.M., Rees, P.M., Rowley, D.B., BekKer, A., Qing, L. \& Hulver, M.L. 1996. Mesozoic assembly of Asia: constraints from fossil floras, tectonics, and paleomagnetism, 371-400. In Yin, A. \& Harrison, M. (eds) The Tectonic Evolution of Asia. Cambridge University Press, Cambridge.

Zimmermann, W. 1930. Die Phylogenie der Pflanzen. 454 pp. Fischer, Jena. 